\title{
Democratizing the Law of Social Distancing
}

\author{
Lindsay F. Wiley*
}

\begin{abstract}
:
Public health emergency statutes should give executive-branch officials clear authority to respond swiftly in a crisis while setting forth principles to guide executive discretion. Statutes already provide specific authorizations and statutory guardrails for individually targeted measures like isolation and quarantine. New legislation is needed to provide similarly specific authorizations and guardrails for compulsory social distancing and face mask orders. Reforms should facilitate democratic accountability for executive-branch decisions in addition to protecting individual rights. This article offers five key principles to guide legislation. First, statutes should mandate transparency, which is critical to secure the public's trust. To ensure compulsory orders are conditioned on a demonstrated threat of significant risk and a suitable fit between the means and clearly stated ends, mandated disclosures should include statements of the strategic purpose orders are intended to serve, the scientific understanding on which they are based, and the criteria for when they can be lifted. Second, statutes should provide officials with a graded range of alternatives to ensure a sustainable emergency response that can be tailored to evolving conditions and understanding. To facilitate a scaled response that balances the risk of contributing to community transmission against other public priorities, classifications of services, businesses, and activities as essential or high-priority should be developed in advance. Third, statutes should provide substantive standards to ensure orders are neutral laws of general applicability that do not discriminate on the basis of religion. Fourth, to enable widespread voluntary compliance and minimize unjust distribution of the benefits and burdens of public health intervention, statutes should mandate that restrictions must be accompanied by financial and other material supports, legal protections, and accommodations for safer alternatives to restricted activities to the greatest extent possible within available resources. Finally, statutes should authorize criminal enforcement against individuals who violate social distancing orders only if executive-branch officials establish that it is the least restrictive alternative available to achieve the government's purpose. These principles should also guide executive officials as they exercise the discretion granted to them under existing statutes.
\end{abstract}

\footnotetext{
* Professor of Law and director of the Health Law and Policy Program, American University Washington College of Law. The author wishes to thank Peter D. Jacobson, Wendy E. Parmet, Debra Perlin, Mariam Seifter, and Ilya Somin for their helpful comments.
} 
TABLE OF CONTENTS

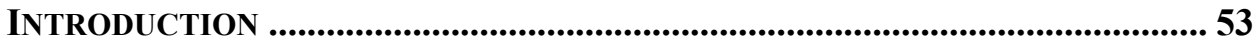

I. Public Health Emergency LaW Before the 2020 Coronavirus

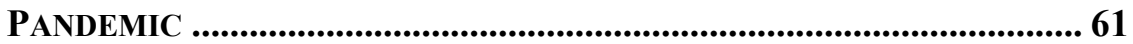

A. TWENTIETH CENTURY FOUNDATIONS .................................................... 61

B. Public Health Law Modernization..................................................... 64

C. SPECIFIC STATUTORY AUTHORITIES FOR SOCIAL DiSTANCING ................. 68

II. THE U.S. RESPONSE TO THE 2020 CORONAVIRUS PANDEMIC.................... 69

A. THE FAILURE OF SCREENING, ISOLATION, AND QUARANTINE TO CONTAIN THE PANDEMIC 70

B. The Use of Social Distancing and Face Masks to Mitigate COMMUNITY TRANSMISSION AND "FLATTEN THE CURVE" ............................ 72

C. THE BREAK-DOWn OF CONSENSUS: Resistance TO Mitigation AND

CALlS TO “CRUSH THE CURVE” BY ACHIEVING SUPPRESSION ...................... 76

III. Community Mitigation IN THE COURTS................................................... 81

A. EMERGENCY STANDARDS OF JUDICIAL REVIEW ……….......................... 83

B. GOVERNMENT ACTION THAT INFRINGES ON FUNDAMENTAL RIGHTS ....... 86

C. ARbitrary, CAPricious, or UnREASONABle GOVERnMENT ACTION.... 94

D. LACK OF STATUTORY AUTHORITY FOR EXECUTIVE ACTION..................... 98

E. SEPARATION OF POWERS CONSTRAINTS ON EXECUTIVE ACTION ............. 101

IV. PROPOSED STATE LEGISLATIVE REFORMS ......................................... 106

A. The Strategic Purpose of ORders, THE SCIENTIFIC UNDERSTANDING ON WHICH THEY ARE BASED, AND CRITERIA FOR LifTING THEM SHOUld BE Disclosed TO THE PUBlic IN SPECIFIC TERMS.

B. STATUtes SHOUld Authorize a GRAdEd RANGE OF INTERVENTIONS AND CLASSIFICATIONS OF SERVICES, BUSINESSES, AND ACTIVITIES AS ESSENTIAL OR High-PRIORITY SHOULD BE DEVELOPED IN ADVANCE.

C. Substantive Standards Should EnSuRE ORDERS ARE NEUTRAL LAWS OF GENERAL APPLICABILITY THAT DO NOT DISCRIMINATE ON THE BASIS OF RELIGION.

D. Statutes Should Mandate Provision of Supportive Measures, 
LEGAL PROTECTIONS, AND ACCOMMODATION OF SAFER ALTERNATIVES TO RESTRICTED ACTIVITIES WITHIN AVAILABLE MEANS.

E. CRIMINAL ENFORCEMENT AGAINST INDIVIDUALS SHOULD BE AUTHORIZED ONLY IF JUSTIFIED AS THE LEAST RESTRICTIVE

ALTERNATIVE 118

CONCLUSION 
SOCIAL DiSTANCING

\section{INTRODUCTION}

Most people had never heard of "social distancing" before 2020. ${ }^{1}$ Now, the term is ubiquitous, but poorly defined. "Social distancing" is often used to describe individual responsibility for staying at least six feet away from people who are not part of their household. ${ }^{2}$ I call that "physical distancing," to distinguish it from the society-wide, government-led measures that are the focus of this Article. ${ }^{3}$ The

1. Measures to "increase social distance" were described in pre-pandemic plans and public health literature in the mid-aughts. See, e.g., CTRS. FOR DisEASE CONTROL \& PREVENTION, PubliC Health Guidance for Community-Level Preparedness and Response to SeVEre ACute Respiratory Syndrome (SARS) Version 2 Supplement D ApP. D1 7 (2004), https:/www.cdc.gov/sars/guidance/d-quarantine/app1.pdf (describing "community-wide measures to increase social distance," as a set of interventions distinct from isolation of the infected and quarantine of the exposed to be applied to "[a]ll members of a community" under specified conditions); Lawrence O. Gostin, Influenza Pandemic Preparedness: Legal and Ethical Dimensions, 34 HASTINGS CTR. RPT. 10, 11 (2004) (describing legal authority to "restrict social mixing and increase social distance" by "closing down civic activities, meeting places, large gatherings, and transportation" as distinct from quarantine and isolation to "separate the infected and exposed from healthy individuals"); Robert J. Glass, Laura M. Glass, Walter E. Beyeler \& H. Jason Min, Targeted Social Distancing Designs for Pandemic Influenza, 12 EMERGING INFECTIOUs DisEASES 1671, 1671 (2006) (describing social distancing in terms of "strategically controlling [social contact networks] during a period of pandemic"). References to "social distance" and "social mixing" were previously used in studies examining the influence of social networks on HIV transmission. See, e.g., Rodrick Wallace, Social Disintegration and the Spread of AIDS: Thresholds for Propagation Along "Sociogeographic" Networks, 33 Soc. SCI. \& MED. 1155 (1991).

2. See, e.g., Social Distancing: Keep a Safe Distance to Slow the Spread, CTRS. FOR DiSEASE Control \& Prevention (last updated Nov. 17, 2020), https://www.cdc.gov/coronavirus/2019ncov/prevent-getting-sick/social-distancing.html.

3. Physical distance is certainly relevant to social distancing, but requiring individuals to maintain a distance of six feet while they otherwise go about their daily lives would probably not be adequate to control the spread of disease. In part, this is because six feet of distance may not be enough to prevent transmission when people spend sustained time together in enclosed poorly ventilated spaces. The scientific understanding of the extent to which SARS-COV-2 is transmitted through small aerosol droplets that drift farther that six feet in enclosed, poorly ventilated spaces has evolved throughout the pandemic. But even in the earliest weeks, a highly influential modeling report assumed that " $[\mathrm{t}] \mathrm{ransmission}$ events occur through contacts made between susceptible and infectious individuals in either the household, workplace, school or randomly in the community, with the latter depending on spatial distance between contacts.” NeIL M. FERGUSOn ET AL., IMPerial College COVID-19 RESPONSE TEAM REPORT 9: IMPACT OF NON-PHARMACEUTICAL INTERVENTIONS (NPIS) TO REDUCE COVID-19 MORTALITY AND HEALTHCARE DEMAND 4 (2020), https://www.imperial.ac.uk /media/imperial-college/medicine/sph/ide/gida-fellowships/Imperial-College-COVID19-NPI-

modelling-16-03-2020.pdf (emphasis added). Thus, the report's authors also advised attention to the "contact-time" between people from different households, which may be small at mass gatherings "compared to the time spent at home, in schools or workplaces and in other community locations such as bars and restaurants." Id. at 8 . More relevant to my point, pre-pandemic plans generally assumed that, to be successful, social distancing interventions would require shared responsibility among governments, private organizations, and individuals. Public health interventions that rely exclusively on individual behavior change tend to be ineffective. Thus, many public health interventions are designed to change the context in which individuals make choices, in addition to 
terms "quarantine" and "lockdown" have been widely used to describe governmental orders aimed at reducing overall contacts during the coronavirus pandemic. But "quarantine" is used by epidemiologists and regulators to refer to targeted restrictions on individuals who are known to have been exposed to infection. "Lockdown," which suggests a binary lockdown/reopen switch, is a poor fit for the varying governmental interventions that have been dialed up or down to adjust overall levels of contact in response to local conditions. I define "social distancing" as a graded range of governmental restrictions and supports to achieve an overall reduction in contacts among the general population, regardless of known exposure or infection (see Figure 1).

providing education and recommendations to guide those choices. See LAWrenCE O. Gostin \& Lindsay F. Wiley, Public Health Law: Power, Duty Restraint 23-26 (3d ed. 2016) (contrasting the behavioral and social-ecological models of public health problem solving).

4. Federal, state, and local statutes specifically authorize isolation of individuals who are reasonably believed to be infected, and quarantine of those who are reasonably believed to have been exposed to infection. See, e.g., Gostin \& WILEY, supra note 3, at 425-28 (reviewing quarantine and isolation authorities). Governments at every level - federal, state, and local - have used a particular type of quarantine, known as a travelers' quarantine, to slow the spread of the coronavirus pandemic. Ross D. Silverman, Contact Tracing, Intrastate and Interstate Quarantine, and Isolation, in ScOTT Burris, Wendy Parmet, \& Lance Gable, eds. COVID-19 Rapid Legal Assessment (2020); see also Gostin \& WILEY, supra note 3, at 424 (discussing travelers' quarantines). Restrictions on travelers may be individually targeted to a degree that compulsory social distancing and face covering requirements are not. Limits on travelers across international, state, and local borders also raise distinct questions regarding the boundedness of communities and communitarianism as a foundational principle on which public health intervention sometimes rests. See BonNIE HonIG, EMERGENCY POlitics: PARADOX, LAW, DeMOCRACY 130 (2009) (discussing the "paradox of bounded communities" and proximity of neighbors as a justification for helping some, but not others, "not as a problem but as an opportunity"). I am setting aside the issue of travelers' quarantines to give it the in-depth treatment it deserves in a follow-up project. 
Figure 1. A Graded Range of Law \& Policy Interventions for Social Distancing Among the General Population

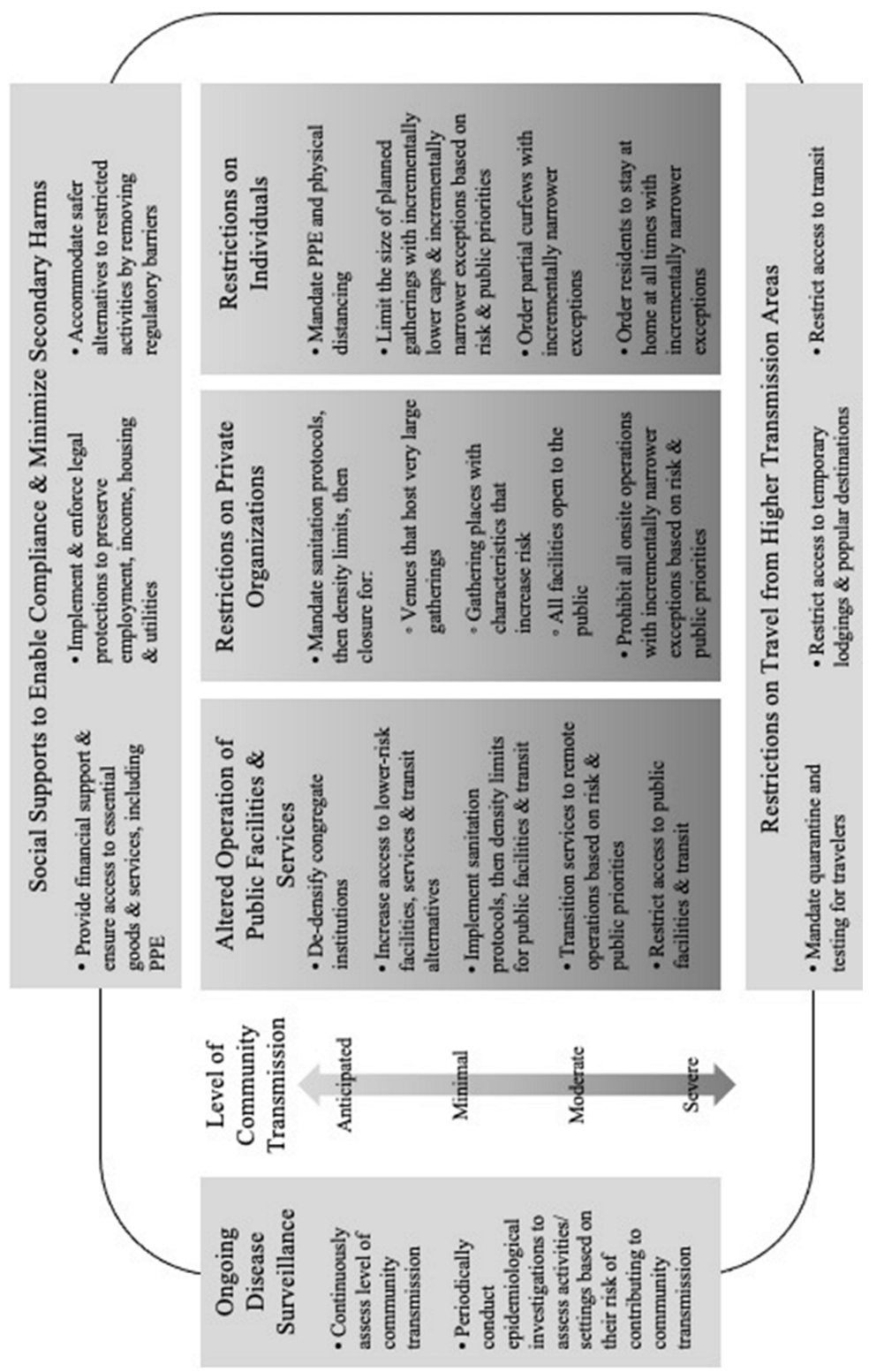

In our treatise, Public Health Law: Power, Duty, Restraint, Professor Lawrence Gostin and I cautioned that compulsory social distancing would raise 
complex questions for which legal precedents provided few answers. "Undoubtedly the courts would uphold reasonable community restrictions," we wrote, "but legal and logistical questions loom: who has the power to order closure, by what criteria, and for what period of time?"5 Compulsory social distancing orders, and orders for the general public to wear face masks or other personal protective equipment (PPE) regardless of infection or exposure, do not fall neatly within specific statutory grants of authority the way quarantine and other individually targeted public health interventions do. Few pre-2020 judicial precedents are directly on point.

Over the last several months, the courts have issued hundreds of decisions defining the boundaries of public health emergency authority. Unsurprisingly, these cases have centered on the two central tensions in public health law: the balance "between the common good and civil liberties" and the balance "between principles of open, transparent, and participatory governance and the need for expertise-driven, efficient, and efficacious government responses to public health problems." Some challengers have argued that emergency orders infringe upon constitutionally protected individual rights. Some have argued that orders exceed the scope of executive officials' statutory authority or that broad statutory delegations to the executive violate state-constitution separation of powers requirements. Some have brought both types of claims - rights-based and structural.

Coronavirus emergency orders and judicial responses to them have evolved throughout the pandemic. In the early months, most judges were hesitant to second-guess executive decisions made under conditions of scientific uncertainty and great peril. On the whole, they took a very forgiving stance toward sweeping public health responses. ${ }^{8}$ As the pandemic has worn on, however, a few courts have begun to move more aggressively to overturn emergency orders and curtail executive authority. ${ }^{9}$ The Supreme Court's recent decision in Roman Catholic

5. Gostin \& Wiley, supra note 3, at 432; see also Lawrence O. Gostin \& Lindsay F. Wiley, Governmental Public Health Powers During the COVID-19 Pandemic: Stay-at-Home Orders, Business Closures, and Travel Restrictions, 323 JAMA 2137 (2020) ("Long-term, compulsory stayat-home orders applicable across a large geographic area are untested in the courts.").

6. Gostin \& WILEY, supra note 3, at 151.

7. Id. at 154 .

8. See Lindsay F. Wiley \& Steve I. Vladeck, COVID-19 Reinforces the Argument for "Regular" Judicial Review-Not Suspension of Civil Liberties-In Times of Crisis, HARV. L. REV. BLOG (April 9, 2020), https://blog.harvardlawreview.org/covid-19-reinforces-the-argument-forregular-judicial-review-not-suspension-of-civil-liberties-in-times-of-crisis; see also Lindsay $\mathrm{F}$. Wiley \& Stephen I. Vladeck, Coronavirus, Civil Liberties, and the Courts: The Case Against 'Suspending' Judicial Review, 133 Harv. L. ReV. F. 179 (2020); Part III.A., infra.

9. See, e.g., County of Butler v. Wolf, No. 2:20-cv-677, 2020 WL 5510690 (W.D. Pa. Sept. 14, 2020) (holding stay-at-home and business closure orders violate the First and Fourteenth Amendments), stayed pending appeal, County of Butler v. Wolf, 2020 WL 5868393 (3d Cir. Oct. 1, 
Diocese of Brooklyn v. Cuomo signals a major shift in the fate of legal challenges to coronavirus emergency orders, just as the third wave of the pandemic hits the United States. ${ }^{10}$ The Court enjoined New York from imposing limits on the plaintiffs' houses of worship that are more restrictive than limits on "essential" businesses. ${ }^{11}$ By applying strict scrutiny, the majority appears to have rejected a doctrine many lower courts have relied on to uphold other types of restrictions. ${ }^{12}$ Many state and local governments will need to retool their approach to compulsory social distancing restrictions in light of this new precedent. ${ }^{13}$ A new wave of emergency orders is coming that will differ from what we have seen so far.

A new wave of legislative reform driven by lessons learned during the pandemic is also on the horizon. Sweeping reforms often follow in the aftermath of an actual or threatened crisis. In the decade after the jetliner and anthrax attacks of 2001, for example, Congress and state legislatures across the country passed hundreds of bills to specify the emergency powers available to executive-branch officials and provide statutory protections for individuals subjected to compulsory medical examinations, testing, quarantine, isolation, and vaccination. ${ }^{14}$ Social distancing and face mask orders, which had not been widely used in the U.S. in decades, got little attention from reformers bent on modernization. ${ }^{15}$ The result hundreds of coronavirus emergency orders resting on older, broader grants of authority with minimal guidance from the legislature - has caused confusion and consternation in the courts. ${ }^{16}$ Now, we are on the cusp of a new decade of reforms.

This Article's aim is to guide development of legislation defining the outer bounds of executive authority to order compulsory social distancing and use of PPE for the general public. In the coming months and years, many state legislatures will codify the law of social distancing that is currently emerging from the courts and from precedent-setting executive orders. Congress could reform federal disease control laws as well. The widely divergent lessons legislators have learned

2020); In re Certified Questions, No. 161492, 2020 WL 5877599, (Mich. Oct. 2, 2020) (holding that a 1945 emergency management statute violates the Michigan constitution's separation of powers requirement by improperly delegating legislative powers to the executive branch). These cases are outliers and the Pennsylvania case is likely to be reversed on appeal, but they may indicate growing frustration with sweeping executive orders and growing desire to curtail similar executive responses in the future.

10. Roman Catholic Diocese of Brooklyn v. Cuomo, 141 S. Ct. 63 (2020).

11. Id.

12. See Part III.A., infra.

13. See Part IV.C, infra.

14. See Part I.B, infra.

15. See, e.g., Lawrence O. Gostin, Scott Burris \& Zita Lazzarini, The Law and the Public's Health: A Study of Infectious Disease Law in the United States, 99 Colum. L. REV. 59, 66 (1999) (indicating that the authors were focused on incorporating "modern scientific and constitutional developments" into state public health statutes).

16. See Part III, infra. 
from the pandemic may simply reinforce existing political divides. Some legislators will seek to strip executive officials of their emergency powers. ${ }^{17}$ Others will prefer to leave broad grants of authority undisturbed, relying on the courts to continue to uphold most executive orders. This Article argues for a middle ground by asserting that reforms are needed to specifically authorize and guide executive action. These reforms could be helpful for ongoing response to the current pandemic - and for the next crisis, which could pose different, and perhaps even greater, threats to the public's health and the rule of law. Legislators who wish to put executive actions on firmer statutory footing should offer reform proposals that respond to concerns about executive overreach without stripping executive powers.

I draw lessons from three sources to inform my recommendations for legislative reform: judicial opinions adjudicating legal challenges to coronavirus emergency orders, ${ }^{18}$ political theories of emergency politics, ${ }^{19}$ and longstanding principles of public health law and ethics. ${ }^{20}$ I largely reject a fourth source of potential guidance: the Model State Emergency Health Powers Act ${ }^{21}$ (MSEHPA) promulgated in the aftermath of the 2001 terrorist attacks in an effort to modernize public health law. These individually targeted measures MSEHPA authorizes are highly restrictive (isolation and quarantine orders may confine individuals with no exceptions for essential work, errands, or outdoor exercise) or invasive (for example, medical tests, examinations, treatments, and vaccination). The statutory guardrails modernization reformers recommended were similarly focused on individuals. Modernization reformers assumed individualized risk assessments (ensured through individual rights to notice, a hearing, and legal representation) ${ }^{22}$

17. See, e.g., S.B. 1166, 2019-2020 Leg., Reg. Sess. (Pa. 2020); S.B. 29, 2020 Leg., 2d Spec. Sess. (La. 2020); S.B. 311, 133d Gen. Assemb., Reg. Sess. (Ohio 2020); Jake Zuckerman, Lawmakers Send Bill to Governor to Kneecap Health Department Authority, OHIO CAPITAL J. (Nov. 19, 2020), https://ohiocapitaljournal.com/2020/11/19/lawmakers-send-bill-to-governor-to-kneecaphealth-department-authority/; Melinda Deslatte, Louisiana COVID-19 Special Session Opens with Power Debate, ASSOCIATED PRESS (Sept. 28, 2020), https://apnews.com/article/virus-outbreak-johnbel-edwards-pandemics-louisiana-archive-e8cfeb44108aea9a30c1498b3de3c1fd; Lawmakers Move

to Limit a Governor's Disaster Powers, Associated Press (July 15, 2020), https://apnews.com/f4e271a1292cb1add64daf41a82a05cf.

18. See Part II, infra.

19. I draw especially heavily on the work of political and legal theorist Bonnie Honig, who argues that emergencies do not, and should not, obviate the fact that there is "no getting away from the need in a democracy for the people to decide." HonIG, supra note 4, at 3 (2009).

20. See Gostin, Burris \& Lazzarini, supra note 15 (laying the groundwork for post-9/11 public health law modernization efforts and offering useful lessons for the coming decade of reforms).

21. Model State Emergency Health Powers Act (MSEHPA) (Ctr. for L. \& Pub.'s HEALTH 2001), http://www.publichealthlaw.net/MSEHPA/MSEHPA.pdf.

22. Id . at $\S 605$ (providing for temporary holds pursuant to written directives, followed by the possibility of a petition for a court order to hold an individual beyond an initial 10-day period, hearing rights, and court-appointed legal counsel). 
and use of the least restrictive alternative ${ }^{23}$ were feasible and possibly constitutionally required.

The requirements many state statutes impose on quarantine orders and other individually targeted measures are simply not feasible for compulsory social distancing and face mask orders. Social distancing is not governed - nor is it governable - by statutory requirements mandating individualized risk assessments $^{24}$ and use of the least restrictive alternative. ${ }^{25}$ Compulsory social distancing is different from quarantine. The statutory constraints that guide and limit its use must also be different. New legislation - which could be guided by the development of a new model $\mathrm{act}^{26}$ - is needed.

As they refine the limits on executive emergency powers in the coming decade, I urge legislatures to consider five key principles, which emphasize public disclosure requirements to promote transparency and accountability in addition to statutory protections for individual rights. First, because widespread voluntary cooperation is the primary means of securing compliance - even for measures that are purportedly mandatory - legislatures should provide clear requirements for transparency and communication, which are critical to secure the public's trust. ${ }^{27}$ To ensure executive officials' use of compulsory powers is conditioned on a demonstrated threat of significant risk $^{28}$ and a suitable fit between the means and clearly stated ends, ${ }^{29}$ this communication should include statements of the strategic purpose orders are intended to serve, the scientific understanding on which they are based, and the criteria that will be relied on to determine whether they are

23. Id. at $\S 604(\mathrm{~b})(1)$ ("Isolation and quarantine must be by the least restrictive means necessary to prevent the spread of a contagious or possibly contagious disease to others.").

24. See, e.g., WISC. STAT. § 252.06(3) (2009) ("If the local health officer is not a physician, he or she shall consult a physician as speedily as possible where there is reasonable doubt or disagreement in diagnosis and where advice is needed [regarding the need for isolation]."). In addition, many provide procedural protections. In some states, quarantine statutes require health officials to obtain a court order for the quarantine to be legally enforceable

25. See, e.g., AlASKa STAT. $§ 18.15 .385(b)(1)$ (2004) ("[I] solation and quarantine shall be by the least restrictive means necessary to prevent the spread of a contagious or possibly contagious disease that poses a significant risk to public health."); id. at $\S 18.15 .385$ (d) (“The department shall file a petition for a written order [from the superior court authorizing the isolation or quarantine]. The petition must allege ... that the individual is unable or unwilling to behave so as not to expose other individuals to danger of infection.").

26. In March of 2020, the Uniform Law Commission has convened a study committeechaired by Diane Boyer-Vine, with Professor Wendy Parmet serving as the reporter-to make a recommendation regarding whether a new uniform act or model act on state emergency health powers would be advisable.

27. See Gostin, Burris \& Lazzarini, supra note 15, at 94-95 (discussing the importance of maintaining the public's trust and cooperation), 120 (recommending that state legislatures recognize voluntary cooperation as the primary means of securing compliance).

28. Id. at 121.

29. See Gostin \& WiLeY, supra note 3, at 60 (discussing means-ends fit as an ethical principle that should guide public health regulation, regardless of whether it is constitutionally required). 
working and when they can be lifted. Time limited, but renewable orders should ensure these statements are periodically updated. Second, public health statutes should provide executive officials with a graded range of alternatives to ensure a sustainable emergency response that can be tailored to adjust to evolving conditions and scientific understanding. ${ }^{30}$ To facilitate a scaled response and promote greater democratic deliberation on policy choices, classifications among businesses and activities based on public priorities should be developed in advance. Third, legislatures should provide statutory guardrails to ensure orders are neutral laws of general applicability that do not discriminate on the basis of religion. Fourth, to enable widespread voluntary compliance and minimize unjust distribution of the benefits and burdens of public health intervention, restrictions and mandates should be accompanied by supports, legal protections, and accommodations to enable compliance with public health guidelines and minimize secondary harms. ${ }^{31}$ I recommend that legislatures require executive officials to implement supportive measures and guidance to the fullest extent possible within available means. Finally, criminal enforcement against individuals who violate social distancing and face mask orders should be authorized only as a last resort. Communication, support for safer alternatives to restricted activities, and administrative sanctions and civil penalties for licensed businesses and other organizations should be prioritized over criminal enforcement. Legislatures should require executive officials to justify criminal enforcement as the least restrictive alternative available to achieve the government's purpose. These principles should also guide executive-branch officials as they exercise their discretion under existing statutes.

This Article proceeds in four parts. In Part I, I describe the evolution of public health emergency law through the turn of the twenty-first century, which determined the governmental powers available at the start of the coronavirus pandemic. In Part II, I describe the community mitigation strategy implemented to slow the spread of the 2020 coronavirus pandemic in the United States after containment efforts failed. In Part III, I map the legal challenges to coronavirus emergency orders adjudicated in state and federal courts and describe their key themes. Finally, I propose statutory guardrails for state legislatures to guide the use of compulsory social distancing and PPE for the general public.

30. Id. at 123-24.

31. See, e.g., Lindsay F. Wiley \& Samuel R. Bagenstos, The Personal Responsibility Pandemic: Centering Solidarity in Public Health and Employment Law 52 ARIz. ST. L.J. (forthcoming 2021). 
SOCIAL DiSTANCING

\section{PUBlic HeAlth EMERGENCY LAW BEFORE THE 2020 CORONAVIRUS PANDEMIC}

In the decades prior to the 2020 coronavirus pandemic, state and local authorities ordered compulsory medical examinations, testing, quarantine, isolation, treatment, and vaccination of individuals to address public health threats ranging from measles, tuberculosis, and syphilis, to HIV, SARS, and Ebola. Following an effort to modernize public health emergency statutes prompted by the HIV epidemic, the 2001 terrorist attacks, the 2003 SARS outbreak, and concerns about novel influenza strains with pandemic potential, these powers are now specifically authorized in most states, via statutes that offer guardrails to guide executive discretion. In contrast, social distancing and face covering had not been widely required for the general public in the United States since the 1918 influenza pandemic and mid-century outbreaks of polio. These measures were largely sidelined in public health emergency law modernization reforms. As a result, 2020 coronavirus orders have largely relied on older, broader grants of authority in public health, disaster management, and civil defense statutes.

\section{A. Twentieth Century Foundations}

In the first half of the twentieth century, local officials frequently exercised broadly defined public health powers to control the spread of disease. State statutes typically authorized local health officials to "make all such ... regulations as they shall deem necessary for the preservation of the public health" 32 or "[t]o do all acts ... which may be necessary or expedient for . . . the suppression of disease." ${ }^{\text {33 }}$ Rarely, state supreme courts found that specific measures, such as vaccination, required specific authorization from the legislature. ${ }^{34}$ More typically, early- and mid-twentieth century courts found broad delegations of public health power constitutionally proper and sufficient to encompass measures that were not authorized in specific terms. ${ }^{35}$ Following the Supreme Court's opinion in Jacobson

32. Kirk v. Board of Health, 65 S.E. 387, 388 (S.C. 1909) (quoting the state statute on which a local health board relied to order a resident infected with leprosy to be isolated).

33. People v. Tait, 103 N.E. 750, 752 (Ill. 1913) (quoting the statute relied on by a local board of health to impose penalties on a parent who sent his child to school while she was ill with scarlet fever).

34. See, e.g., State v. Burdge, 70 N.W. 347 (Wis. 1897) (finding the state board of health lacked properly delegated power to adopt a compulsory vaccination rule absent a specific legislative authorization); $c f$. Mathews v. Kalamazoo Bd. of Educ., 86 N.W. 1036 (Mich. 1901) (finding that local school boards did not have statutory authority to require vaccination absent a specific legislative authorization).

35. See, e.g., People ex rel. Lieberman v. Van De Carr, 67 N.E. 913, 914 (N.Y. 1903) aff'd sub nom. New York v. Van De Carr, 199 U.S. 552 (1905) (finding that "[t]he vesting of powers more or less arbitrary in various officials and boards is necessary, if the work of prevention and regulation is to ward off fevers, pestilence, and the many other ills that constantly menace great centers of 
v. Massachusetts ${ }^{36}$ and analogous state court decisions, courts typically required that compulsory quarantine, isolation, and vaccination must be justified by "public necessity" 37 and must not be "oppressive, arbitrary or unreasonable." 38

Jacobson, decided in 1905, was a "nuanced and Delphic opinion"39 articulating the tensions between individual liberties and public health necessities and between executive flexibility and judicial review. The Court upheld a Massachusetts statute empowering municipal boards of health to mandate vaccination for smallpox. The decision offered a ringing endorsement of public health as a counterweight to individual rights: "the rights of the individual in respect of his liberty may at times, under the pressure of great dangers, be subjected to such restraint, to be enforced by reasonable regulations, as the safety of the general public may demand." The Court also endorsed judicial deference to the scientific findings of experts exercising authority delegated by the legislature. Concluding that " $[t]$ he authority to determine for all what ought to be done in such an emergency must have been lodged somewhere or in some body," the Court approved the legislature's choice "to refer that question, in the first instance, to a board of health composed of persons . . . appointed . . . because of their fitness to determine such questions. ${ }^{, 40}$ The Court repeatedly noted the presence of a statutory standard authorizing local officials to make vaccination compulsory "only when, in the opinion of the board of health, that was necessary for the public health or the public safety." 41

The Jacobson Court also recognized constitutional limits on the board's discretion, reasoning that the "power of a local community to protect itself against an epidemic ... might be exercised in particular circumstances and in reference to particular persons in such an arbitrary, unreasonable manner, or might go so far beyond what was reasonably required for the safety of the public, as to authorize

population"); Kirk, 65 S.E. at 389 (finding that a state statute authorizing local health boards to make rules and regulations "as they deem necessary for the preservation of the public health" was not an unconstitutional delegation of legislative power); McCandless v. Campbell, 20 Haw. 411, 417 (1911) (describing delegation of "the power to enact regulations concerning the public health" to municipal corporations or local boards of health as an "exception" to the "established doctrine of constitutional law that the power conferred upon the legislature to make laws cannot be delegated to any other body or authority").

36. 197 U.S. 11, 26 (1905).

37. Kirk, 65 S.E. at 390; People v. Tait, 103 N.E. at 752.

38. Huffman v. District of Columbia, 39 A.2d 558, 560 (D.C. 1944).

39. Wendy E. Parmet, Rediscovering Jacobson in the Era of COVID-19, 100 B.U. L. REV. ONLINE 117, 119 (2020).

40. Jacobson, 197 U.S. at 27; see also New York v. Van De Carr, 199 U.S. 552, 561 (1905) (describing Jacobson as having "sustained a compulsory vaccination law which delegated to the board of health of cities or towns the determination of the necessity of requiring the inhabitants to submit to compulsory vaccination").

41. Jacobson, 197 U.S. at 27. 
or compel the courts to interfere for the protection of such persons." ${ }^{42}$ Following prevailing standards of the time, ${ }^{43}$ the Court limited judicial review to cases where "a statute purporting to have been enacted to protect the public health, the public morals, or the public safety, has no real or substantial relation to those objects, or is, beyond all question, a plain, palpable invasion of rights secured by the fundamental law."44

State and local officials imposed socially disruptive measures to slow the spread of disease among the general population regardless of infection or exposure in response to the 1918 influenza pandemic and mid-century polio outbreaks. In the 1918 flu pandemic, many U.S. cities and a few states ordered bars, saloons, theaters, churches, and schools to close and prohibited gatherings. ${ }^{45}$ Some went further and closed many types of retail stores. ${ }^{46}$ Many local governments ordered the general public to wear face masks. ${ }^{47}$ Legal challenges were largely rejected by the courts, which described the flu pandemic orders as "reasonable measures to slow the spread of disease." ${ }^{48}$ In the aftermath of the pandemic, at least some

42. Id. at 28 .

43. See Parmet, supra note 39, at 131 (arguing that in Jacobson the Supreme Court recognized for the first time that the Constitution provides some protection for bodily integrity); Josh Blackman, What Rights Are "Essential"? The 1st, 2nd, and 14th Amendments in the Time of Pandemic, 44 HARV. J. L. \& PUB. POL'Y (forthcoming 2021) (manuscript at 43) (arguing that 'Jacobson was decided during a time when the Due Process Clause of the Fourteenth Amendment was understood to prohibit 'arbitrary' or 'irrational' forms of legislation[, b]ut that standard of review did not resemble the modern rational basis test").

44. Jacobson, 197 U.S. at 31.

45. In October 1918, the U.S. Surgeon General issued a bulletin advising state and local public health boards to prohibit public gatherings and order churches, theaters, saloons, and similar gathering places to close, and many complied. Jason Marisam, Local Governance and Pandemics: Lessons from the 1918 Flu, 85 U. DET. MERCY L. REV. 347 (2008); see also Nancy Tomes, "Destroyer and Teacher": Managing the Masses During the 1918-1919 Influenza Pandemic, 125 PuB. HeAlth RPTS 48 (2010) (describing the social history of state and local decisions about social distancing and community hygiene in the 1918 pandemic).

46. Tomes, supra note 45.

47. Marisam, supra note 45, at 360; see also Bradford Luckingham, To Mask or Not to Mask: A Note on the 1918 Spanish Influenza Epidemic in Tucson, 25 J. ARIZ. HISTORY, 191, 194 (1984) (discussing Tuscon's mask mandate and related criminal enforcement actions).

48. See, e.g., Alden v. State, 179 P. 646 (Ariz. 1919) (rejecting a habeas corpus petition by a movie theater owner arrested for violating a local health board order); Globe Sch. Dist. v. Bd. of Health, 179 P. 55 (Ariz. 1919) (denying an injunction of a local health board order declaring it "unlawful for two or more persons to congregate in the United States post office, any bank, store, meat market, or other business house, shooting gallery, pool hall, theater, motion picture show, skating rink, lodge, church, school, social gathering, card party, or other place of amusement or entertainment in the city of Globe or vicinity."). But see Bd. of Health v. Clayton, 106 A. 813 (N.J. 1919) (upholding a lower court order setting aside a conviction of the defendant saloon owner for "invit[ing] people to congregate in his saloon ... such an action being dangerous to human life and health, there being an epidemic of influenza in Paterson ...."); Luckingham, supra note 47 (discussing an unpublished judicial order invalidating a Tucson board of health order mandating face masks on the grounds that an exception for school children rendered it underinclusive and therefore 
legislatures adopted provisions specifically authorizing state and local health officials to regulate gatherings and close gathering places and schools, though only a few states currently have such provisions in place. ${ }^{49}$ To mitigate midcentury polio outbreaks, local authorities again relied on efforts to decrease social mixing by periodically closing schools, swimming pools, libraries, theaters, and other gathering places during the peak of local outbreaks. ${ }^{50}$

\section{B. Public Health Law Modernization}

In the late twentieth and early twenty-first centuries, public health law experienced a renaissance. The emergence of HIV prompted reexamination of statutory authorities. ${ }^{51}$ Public health law scholars noted that "public health statutes across the country reflect[ed] an approach to communicable disease fashionable in the [early twentieth] century." 52 Moreover, they did "not reflect significant contemporary developments in constitutional and public health law."53 Gostin and others warned against relying on modern courts to follow Jacobson's "highly submissive" standard of review. ${ }^{54}$ Professor Wendy E. Parmet suggested that modern courts would review a quarantine regulation "for the procedural protections it provides, and for its reasonableness." 55 Gostin's warning was more dire. He asserted that "criteria in public health statutes for depriving an individual of liberty would be likely to be held constitutionally invalid if challenged in court today." ${ }^{, 56}$ Many states passed legislation in the late 1980s to update quarantine powers. The emphasis was on procedural protections to ensure an individualized

it violated the Equal Protection Clause).

49. See In re Certified Questions, No. 161492, 2020 WL 5877599, at*32 (Mich. Oct. 2, 2020) (Viviano J., concurring in part and dissenting in part) (noting that a "1919 law passed in the wake of the influenza epidemic" was the predecessor to the state's modern provision, Mich. C. L. 333.2253).

50 See DAVid M. Oshinsky, Polio: An AMERican Story 2 (2005) ("[In early June [1949], the [San Angelo, Texas] city council voted to close all indoor meeting places for a week .... [theaters went dark, the municipal swimming pool was closed, and churches suspended service for one Sunday, and] bars and bowling alleys shut their doors."); $i d$. at 346 ("Public events were cancelled, and swimming pools, movie theaters, and libraries were closed [in Hickory, North Carolina in the summer of 1944]"); id. photo of a 1952 March of Dimes poster (recommending to parents that children should refrain from "mix[ing] with new groups" during polio outbreaks).

51. Scott Burris, Rationality Review and the Politics of Public Health, 34 Villanova L. Rev. 933 (1989); Wendy Parmet, AIDS and Quarantine: The Revival of an Archaic Doctrine, 14 HOFSTRA L. REV. 53 (1985); Kathleen M. Sullivan \& Martha A. Field, AIDS and the Coercive Power of the State, 23 Harv. C.R.-C.L. L. Rev. 139 (1988).

52. Larry O. Gostin, The Future of Communicable Disease Control: Toward a New Concept in Public Health Law, 64 MilbanK Q. 79, 79 (1986).

53. Parmet, supra note 51, at 54-55.

54. Gostin, supra note 52, at 86; see also Burris, supra note 51, at 33 (questioning "precisely how much of Jacobson remains viable").

55. Parmet, supra note 51, at 77 (emphasis added).

56. Gostin, supra note 52, at 86 (emphasis added). 
assessment of the risk the subject posed of transmitting infection to others, as well as substantive standards requiring "that restrictions on freedom represent the 'least restrictive alternative' available to achieve a 'compelling state interest.",57

In a foundational 1999 law review article, Professors Scott Burris and Zita Lazzarini joined Gostin to set forth an ambitious agenda for ongoing efforts to reform infectious disease control law. ${ }^{58}$ They offered several key principles to guide modernization efforts. Three of their recommendations are particularly relevant for my purposes. First, legislatures should recognize that voluntary cooperation is the primary means of securing compliance with disease control interventions, even when they are purportedly mandatory. ${ }^{59}$ Second, executive officials' use of compulsory powers should be conditioned on a demonstrated threat of significant risk. ${ }^{60}$ Third, public health statutes should provide executive officials with a graded range of alternatives and use of the least restrictive alternative should be mandated by law. ${ }^{61}$

In the aftermath of the jetliner and anthrax attacks of $2001,{ }^{62}$ Gostin's call for "a coherent statutory basis for the future of public health law" ${ }^{63}$ In collaboration with other experts, he drafted a model state statute to guide reforms. In October 2001, they released the Model State Emergency Health Powers Act (MSEHPA), funded by the Centers for Disease Control and Prevention. ${ }^{64}$ The MSEHPA was controversia ${ }^{65}$ but influential. By the fifth anniversary of the $9 / 11$ attacks, 38 states and the District of Columbia had passed a total of 66 bills or resolutions that included provisions from or closely related to the MSEHPA. ${ }^{66}$ Many of these

57. Albert R. Jonsen \& JefF Stryker, eds., The Social Impact of AIDS in the US 35 (1993).

58. Gostin, Burris \& Lazzarini, supra note 15, at 119.

59. Id. at $94-95,120$.

60. Id. at 121.

61. Id. at 123-24.

62. Gostin \& Wiley, supra note 3, at 401 ("A week after the terrorist attacks of September 11,2001 , letters containing anthrax bacteria were mailed from Trenton, New Jersey to the three major network news stations in New York City, and to two tabloid newspapers, sickening twenty-two people and killing five.").

63. Gostin, supra note 52, at 79.

64. MSEHPA, supra note 21.

65. Among other groups, the American Civil Liberties Union criticized the MSEHPA for failing to include sufficient safeguards for individual liberty, privacy, and equality, for defining public health emergency too broadly and thus creating an opportunity for state officials to use emergency powers in response to diseases for which compulsory quarantine and treatment are unwarranted. $Q \& A$ on the Model State Emergency Health Powers Act, Am. Civ. LiBerTiEs Union, https://www.aclu.org/other/model-state-emergency-health-powers-act (last visited Oct. 13, 2020). Some public health law scholars were highly critical of the MSEHPA's inadequate protections for civil liberties. E.g., George J. Annas, Bioterrorism, Public Health, and Human Rights, 21 HeAlth AFF. 94, 94-95 (2002).

66. The Center for Law \& the Public's Health, The Model State Emergency Health Powers ACt (MSEHPA) State Legislative Activity (2006), http://www.publichealthlaw.net 
statutes specifically empowered state officials to declare a public health emergency, which would trigger authorizations for state and local health officials to issue disease control orders. ${ }^{67}$ Emergency declarations were typically timelimited, but renewable. ${ }^{68}$

The public health emergency provisions in the MSEHPA and the state legislation it inspired focused predominantly on individually targeted measures to achieve containment — stopping the spread of infection from initial cases (typically international travelers) to other people before community transmission becomes widespread, primarily through screening, isolation, and quarantine of individuals. ${ }^{69}$ They had paid scant attention to community mitigation compulsory social distancing and use of personal protective equipment (PPE) by the general public to flatten the curve of the epidemic when containment has failed. ${ }^{70}$

MSEHPA/MSEHPA\%20Leg\%20Activity.pdf.

67. Lainie Rutkow, An Analysis of State Public Health Emergency Declarations, 104 AM. J. Pub. HEAlth 1601, 1601 (2014).

68. Id.

69. See Rochelle P. Walensky \& Carlos del Rio, From Mitigation to Containment of the COVID-19 Pandemic: Putting the SARS-CoV-2 Genie Back in the Bottle, 323 JAMA 1889, 1889-90 (2020) ("As part of pandemic preparedness, epidemiologists promote 'containment strategies' designed to prevent community transmission."); see also MiQUEL PORTA, ED., A DictionARY OF EPIDEMIOLOGY 51 ( $5^{\text {th }}$ ed. 2008) (defining containment as "regional eradication of communicable disease").

70. Walensky \& del Rio, supra note 69, at 1889 ("When disease outpaces containment, countries rely on 'mitigation strategies.' Countries like China, Italy, Spain, and the U.S. moved from containment [of the coronavirus pandemic] to mitigation, albeit at differing paces."). The nowubiquitous phrase "flatten the curve" refers to a mitigation strategy identified through historical analysis of the 1918 influenza pandemic and endorsed in U.S. pandemic influenza plans in 2007. See Ctrs. FOR Disease Control \& Prevention, Interim Pre-PANDEMic Planning GUIDANCE 9 (2007) ("Reshaping the demand for healthcare services by using [nonpharmaceutical interventions (NPIs), including social distancing] . . . means reducing the burdens on the medical and public health infrastructure by decreasing demand for medical services at the peak of the epidemic and throughout the epidemic wave; by spreading the aggregate demand over a longer time; and, to the extent possible, by reducing net demand through reduction in patient numbers and case severity ... . Recent preliminary analyses of cities affected by the 1918 pandemic show a highly significant association between the early use of multiple NPIs and reductions in peak and overall death rates."); see also Noreen Qualls et al., Community Mitigation Guidelines to Prevent Pandemic Influenza - United States, 2017, 66 Morbidity \& Mortality WeEKLY RePORT 1, 18 (2017) ("Although there is limited empirical evidence supporting the effectiveness of implementing any individual measure alone (other than school closures and dismissals), the evidence for implementing multiple social-distancing measures in combination with other NPIs includes systematic literature reviews, historical analyses of the 1918 pandemic, and mathematical modeling studies."). Some experts have advocated for a stronger response to the coronavirus pandemic aimed at suppression - crushing the curve to very low levels of community transmission. See Walensky \& del Rio, supra note 69, at 1889 ("For . . COVID-19, countries like South Korea-an example of successful containment - had a coordinated governmental response, testing on a massive scale, and prompt contact tracing and quarantine."). 
The term social distancing first appeared in the mid-aughts in federal plans to guide state and local responses to coronavirus and flu epidemics. A January 2004 CDC plan for possible resurgence of SARS used the phrase "community-wide measures to increase social distance," to describe this strategy as something distinct from isolation of the infected and quarantine of the exposed. ${ }^{71}$ Social distancing was designed to apply to "[a]11 members of a community in which 1) extensive transmission ... is occurring, 2) a significant number of cases lack clearly identifiable epidemiologic links at the time of evaluation, and 3) restrictions on persons known to have been exposed [i.e., quarantines] are considered insufficient to prevent further spread." 72 A 2005 Homeland Security Council strategy for pandemic influenza advised that individuals and families should be prepared for "limitation of attendance at public gatherings and nonessential travel for several days or weeks."73 The 2006 plan for implementing this strategy addressed the timing of different degrees of social distancing measures, noting that "[1] ow-cost or sustainable social distancing measures" such as holding work meetings via teleconference and advising individuals to keep a physical distance of three to six feet from others "should be introduced immediately after a community outbreak begins." 74 The plan noted that more disruptive measures, such as "snow day" closures of all schools and workplaces, "can be sustained only for limited periods" and "should be reserved for situations in which the need for disease containment is critical.",75

Prior to 2020, the few reports that discussed sheltering in place for the general population broached it as a voluntary measure, and one on which experts disagreed. ${ }^{76}$ Several empirical and policy evaluations of social distancing and other community mitigation measures were published in the academic literature, but few seriously contemplated long-term orders to shelter in place and cease all nonessential business operations. ${ }^{77}$ The SARS-CoV and influenza strains on which

71. Ctrs. for Disease Control \& Prevention, Public Health Guidance for Community-Level Preparedness and Response to SEvere Acute Respiratory SYNDROME (SARS) VERSION 2 SuPPlEMENT D APP. D1 7 (2004), https://www.cdc.gov /sars/guidance/d-quarantine/app1.pdf.

72. Id.

73. Homeland Sec. Council, National Strategy for Pandemic Influenza 11 (2005).

74. Homeland Sec. Council, National Strategy For Pandemic Influenza: IMPLEMENTATION PLAN 108 (2006).

75. Id.

76. See, e.g., Julia E. Aledort et al., Non-Pharmaceutical Public Health Interventions for Pandemic Influenza: An Evaluation of the Evidence Base, 7 BMC PuB. HeAlth 208, 211 tbl.3, 213 fig.1 (2007) (assessing "voluntary sheltering" at home - defined as "sequestration of healthy persons to avoid exposure"-in consultation with an expert panel, which was in disagreement as to its advisability).

77. See, e.g., World Health Organization Writing Group, Nonpharmaceutical Interventions for Pandemic Influenza, National and Community Measures, 12 EMERGING InfeCtious DiseASES 88, 
these plans were based were more lethal than SARS-CoV-2 (the novel coronavirus strain that causes COVID-19), ${ }^{78}$ but easier to control - in part because they did not spread through significant asymptomatic or pre-symptomatic transmission. Specific provisions authorizing health officials to order limits on gatherings and closure of gathering places for the general population were not added to state public health emergency statutes in many jurisdictions, in spite of pandemic preparedness plans indicating they may be needed.

\section{Specific Statutory Authorities for Social Distancing}

Some states do have specific statutory provisions authorizing bans on gatherings or assemblages, closure of schools, and personal movement controls, but these provisions do not encompass all conceivable compulsory social distancing measures. Some of these statutory provisions specifically refer to public health necessities, while others refer only to ensuring public safety or public order. Some require the declaration of an emergency or disaster pursuant to statutory criteria and (typically renewable) time limits, but others do not.

In a few states, health officials are specifically authorized to prohibit gatherings and to close schools and other gathering places. For example, Colorado's public health statute includes a 2008 provision authorizing local public health agencies " $[\mathrm{t}] \mathrm{o}$ close schools and public places and to prohibit gatherings of people when necessary to protect public health," 79 but this provision does not clearly encompass closures of private businesses. ${ }^{80}$ Wisconsin has a similar, but slightly broader provision empowering the state health department to "close schools and forbid public gatherings in schools, churches, and other places to

89-90 (2006) (describing social distancing as involving cancellation of mass gatherings and closure of schools, colleges, theaters, and other public gathering places); Aledort et al., supra note 76 (A panel of experts advised that "community restrictions could be considered on a case-by-case basis, for example, cancellation of an event to which thousands would travel. However, efforts to forcibly limit public assembly or movement were seen as legally and ethically problematic, especially when there is limited scientific evidence supporting such restrictions .... [Though] less invasive voluntary efforts to reduce social contact, especially self-isolation of the sick at home, self-quarantine of the exposed, and, when feasible, sheltering by the well ought to be widely supported [by the general public].”) (emphasis added).

78. SARS-CoV was a distinct strain from SARS-CoV-2. It had a case-fatality rate of about 1015\%. Update 49: SARS Case Fatality Ratio, Incubation Period, World HEALTH ORG. (May 7, 2003), https://www.who.int/csr/sars/archive/2003 05 07a/en/.

79. Colo. Rev. Stat. § 25-1-506(3)(b)(VII) (2013); S.B. 08-194, 66th Gen. Assemb., Reg. Sess. (Colo. 2008).

80. See Larimer Cty. Pub. Health v. Maniacs Gym, 2020 WL 1943829 (Apr. 1, 2020) (relying on the local public health agency's quarantine power, and not its power to close "public places" or "prohibit gatherings" to issue a preliminary injunction against the owner of a gym which remained open to members in defiance of a local order prohibiting nonessential on-site business operations). 
control outbreaks and epidemics," 81 but this provision may not encompass prohibitions on private house parties. ${ }^{82}$ Neither of these authorities is contingent on a formal emergency declaration.

Some of the most sweeping authorities to control personal movement are found in civil defense, emergency, and disaster statutes enacted in the World War II, Civil Rights, and Vietnam War eras. ${ }^{83}$ These provisions, aimed at equipping governors to quell civil unrest, were not adopted with communicable disease threats foremost in legislators' minds, but were generally drafted broadly enough to encompass pandemics as "naturally occurring" disasters or emergencies. For example, a provision in Massachusetts's Civil Defense Act, adopted in 1950, grants the governor authority "related to ... [a]ssemblages, parades or pedestrian travel, in order to protect the physical safety of persons or property." 84 Pennsylvania's disaster management statute, adopted in 1978, authorizes the governor to "[c]ontrol ingress and egress to and from a disaster area, the movement of persons within the area and the occupancy of premises therein," ${ }^{\prime \prime 5}$ a provision drafted broadly enough to encompass all movements, whether in public areas or privately owned premises. California's Emergency Services Act, adopted in 1970, includes the broadest possible delegation to the executive. During a declared emergency, it grants the governor "the right to exercise within the area designated all police power vested in the state by the Constitution and laws of the State of California in order to effectuate the purposes of [emergency mitigation and protection of health and safety]." 86

\section{THE U.S. RESPONSE TO THE 2020 CORONAVIRUS PANDEMIC}

To slow the spread of the coronavirus pandemic, all fifty governors and many tribal, local officials have exercised broad powers available to them under public health statutes and emergency declarations to alter the operations of businesses and other organizations and to restrict the movement of individuals. ${ }^{87}$ After

81. Wisc. STAT. § 252.02(3) (2015) (emphasis added).

82. See Wis. Legislature v. Palm, 942 N.W.2d 900, 970 (2020) (Hagedorn, J., dissenting) (noting that the plaintiffs appear to acknowledge statutory authority to close schools and churches and forbid other "public gatherings" but argue those powers do not authorize the full range of restrictions imposed in the stay-at-home order).

83. Patrick S. Roberts, Disasters AND the American State 127-145 (2013).

84. MASS. GEN. LAWS ch. 639, § 7(g) (1950).

85. 35 Pa. Cons. Stat., §7301(f)(7) (2014); see also AlaSka Stat. § 26.23.020(g)(7) (2004) (accord); GA. CODE ANN. § 38-3-51(d)(7) (2010) (accord); LA. REV. STAT. § 29-724 (C)(3) (accord).

86. CAL. GOV’T CODE $\S 8627$ (West 2017) (emphasis added).

87. Jennifer Kates, Josh Michaud \& Jennifer Tolbert, Stay-at-home Orders to Fight COVID19 in the United States: A Scattershot Approach, KAISER FAmily Found. (Apr. 5, 2020), https://www.kff.org/coronavirus-policy-watch/stay-at-home-orders-to-fight-covid19

[https://perma.cc/WXK4-BCPU]; see also State Actions to Mitigate the Spread of COVID-19, 
containment measures failed in the United States and United Kingdom, an influential report released by the Imperial College of London's COVID-19 Task Force in mid-March modeled the impact of multilayered nonpharmaceutical interventions, also known as community mitigation measures, which the task force assumed would be necessary to reduce peak impacts on health systems. ${ }^{88}$ The report concluded that while we wait for widespread distribution and acceptance of a safe and effective vaccine, some degree of community mitigation may be needed on an intermittent basis - in some places at some times - for 18 months or more. ${ }^{89}$

\section{A. The Failure of Screening, Isolation, and Quarantine to Contain the Pandemic}

In January 2020, in response to reports of a pneumonia outbreak in Wuhan, China caused by a novel coronavirus strain, federal officials initiated containment measures to prevent the epidemic from reaching the U.S. The containment strategy relied on federal, state, and local communicable disease control authorities to screen and identify infected and exposed travelers entering the U.S. from China and isolate or quarantine them. Public health entry screening began at major international airports in the U.S. on January $17,,^{90}$ but there is no evidence that airport screening resulted in detection of any reported cases during the containment phase. ${ }^{91}$ Two Americans who had recently returned from Wuhan tested positive for the novel coronavirus on January 21 and 24 after arriving at hospitals with symptoms; they were treated in isolation rooms. ${ }^{92}$ The State Department

KAISER FAMILY FOUND., https://www.kff.org/health-costs/issue-brief/state-data-and-policy-actionsto-address-coronavirus/\#socialdistancing [https://perma.cc/4HYP-BKLU] (last visited June 5, 2020) (tracking state social-distancing executive orders).

88. See FERGUSON ET AL., supra note 3, at 6-7.

89. Id. at 15.

90. Public Health Screening to Begin at 3 U.S. Airports for 2019 Novel Coronavirus ("2019$\left.n C o V^{\prime \prime}\right)$ CTRS. FOR Disease CONTROL \& Prevention (Jan. 17, 2020), https://www.cdc.gov/media/releases/2020/p0117-coronavirus-screening.html; First Travel-Related Case of 2019 Novel Coronavirus Detected in United States, CTRS. FOR DisEASE CONTROL \& PreVENTION (Jan. 21, 2020), https://www.cdc.gov/media/releases/2020/p0121-novel-coronavirustravel-case.html (describing expansion of public health entry screening to additional airports).

91. Out of 256 individuals across 34 jurisdictions for whom CDC staff recommended testing in January 2020 - at a time when testing was available in the U.S. solely through CDC - six were identified through airport screening. CDC did not specify whether any of the six identified through airport screening were among the 11 who tested positive in the U.S. in January. Kristina L. Bajema, et al., Persons Evaluated for 2019 Novel Coronavirus - United States, January 2020, 69 MORBIDITY \& MORTALITY WEEKLY REPORT 166 (2020).

92. First Travel-Related Case of 2019 Novel Coronavirus Detected in United States, supra note 90; Second Travel-Related Case of 2019 Novel Coronavirus Detected in United States, CTRS. FOR Disease CONTROL \& PREVEntion (Jan. 24, 2020), https://www.cdc.gov /media/releases/2020/p0124-second-travel-coronavirus.html. 
repatriated hundreds of Americans from Wuhan. ${ }^{93}$ Under the first federal quarantine order issued in more than 50 years, ${ }^{94}$ they were held in governmentprovided facilities while being monitored for symptoms and tested for infection. ${ }^{95}$ On January 30, CDC reported the first instance of human-to-human transmission occurring within the U.S. - between one of the first travel-acquired cases and a household contact. ${ }^{96}$ The following day, Health and Human Services Secretary Alex Azar declared a Public Health Emergency, ${ }^{97}$ formalizing efforts to support development and distribution of diagnostic tests, therapeutics, and vaccines.

It was evident by late February that moderate community transmission was occurring in multiple regions of the U.S. in spite of containment efforts. Individuals who had not travelled overseas and did not appear to have encountered someone previously known to have been infected were testing positive for COVID-19. ${ }^{98}$ In an effort to encourage self-isolation, many state and local health departments issued recommendations or orders directing people to stay home if they had symptoms characteristic of coronavirus infection. ${ }^{99}$ But reports from China, Germany, and elsewhere indicated that asymptomatic or pre-symptomatic individuals were capable of transmitting infection to others, rendering guidance focused on people who were symptomatic inadequate to achieve containment. ${ }^{100}$

93. HHS and CDC Receive Flight Carrying Repatriated US Citizens, CTRS. FOR DISEASE Control \& Prevention (Jan. 29, 2020), https://www.cdc.gov/media/releases/2020/s0129repatriated-US-citizens.html.

94. Transcript for CDC Media Telebriefing: Update on 2019 Novel Coronavirus (2019- $n$ CoV), CTRS. FOR DisEASE CONTROL \& PREVENTION (Jan. 31, 2020), https://www.cdc.gov /media/releases/2020/t0131-2019-novel-coronavirus.html.

95. CDC Issues Federal Quarantine Order to Repatriated U.S. Citizens at March Air Reserve Base, CTRS. FOR DiSEASE CONTROL \& PREVENTION (Jan. 31, 2020), https://www.cdc.gov /media/releases/2020/s0131-federal-quarantine-march-air-reserve-base.html.

96. CDC Confirms Person-to-Person Spread of New Coronavirus in the United States, CTRS. FOR Disease CONTROL \& PREVEnTION (Jan. 30, 2020), https://www.cdc.gov /media/releases/2020/p0130-coronavirus-spread.html.

97. Health \& Human Svs. Sec'y Alex Azar, Determination that a Public Health EMERGENCY EXISTS (Jan. 31, 2020), https://www.phe.gov/emergency/news /healthactions/phe/Pages/2019-nCoV.aspx.

98. See CDC Confirms Possible Instance of Community Spread of COVID-19 in U.S., CTRS. FOR DiSEASE CONTROL \& PREVENTION (Feb. 26, 2020), https://www.cdc.gov/media /releases/2020/s0226-Covid-19-spread.html; CDC Announces Additional COVID-19 Presumptive Positive Cases, Ctrs. FOR Disease COnTrol \& Prevention (Feb. 28, 2020), https:/www.cdc.gov/media/releases/2020/s0228-additional-COVID-19-cases.html.

99. See, e.g., Local Health Officials Announce New Recommendations to Reduce Risk of Spread of COVID-19, KING COUNTY (Mar. 4, 2020), https://www.kingcounty.gov/depts /health/news/2020/March/4-covid-recommendations.aspx.

100. Matt Apuzzo, Selam Gebrekidan \& David D. Kirkpatrick, How the World Missed COVID19's Silent Spread, N.Y. TIMES (Jun. 27, 2020), https://www.nytimes.com/2020/06/27 /world/europe/coronavirus-spread-asymptomatic.html; Ruiyun Li et al., Substantial undocumented infection facilitates the rapid dissemination of novel coronavirus (SARS-CoV-2), 368 SCIENCE 489 (2020). 
Several countries ramped up widespread testing and contact tracing to contain or suppress the spread of asymptomatic infection. But in the U.S., these efforts were slow to start and were quickly outpaced by widespread community transmission. The FDA initially restricted testing to labs that had obtained special approval. ${ }^{101}$ Early CDC guidelines sharply limited which patients should be referred for testing. ${ }^{102}$ Testing supplies were scarce. ${ }^{103}$ Lack of access to testing left people unsure about whether they posed a risk of transmitting the virus to others and state and local leaders ill equipped to deploy individually targeted disease control strategies.

\section{B. The Use of Social Distancing and Face Masks to Mitigate Community Transmission and "Flatten the Curve"}

Initially, public health messages aimed at the general public urged people to maintain a distance of 6 feet from people outside of their households, to wash hands frequently, to wear face masks only if sick, and to work from home if possible. But as reports of overwhelmed hospitals in Italy dominated U.S. media, ${ }^{104}$ and as scientific understanding of the public health threat evolved, guidance - and eventually mandatory orders - changed rapidly. Public health experts sounded the alarm, urging governments and institutions to act immediately to "flatten the curve" and protect hospital capacity by implementing social distancing plans. ${ }^{105}$

In mid-March, federal guidelines struggled to keep pace with the restrictions imposed by state and local governments. On March 12, CDC quietly posted a

101. Lab Advisory: Reminder: COVID-19 Diagnostic Testing, CTRS. FOR DISEASE CONTROL \& PREVENTION (Feb. 18, 2020), https://www.cdc.gov/csels/dls/locs/2020/reminder covid19 diagnostic testing.html.

102. Update and Interim Guidance on Outbreak of 2019 Novel Coronavirus (2019-nCoV), Ctrs. FOR Disease Control \& PREVEnTiOn (Feb. 1, 2020), https://emergency.cdc.gov /han/han00427.asp.

103. Michael D. Shear et al., The Lost Month: How a Failure to Test Blinded the U.S. to Covid19, N.Y. Times (Mar. 28, 2020), https://www.nytimes.com/2020/03/28/us/testing-coronaviruspandemic.html ("[A]s the deadly virus spread from China with ferocity across the United States between late January and early March, large-scale testing of people who might have been infected did not happen - because of technical flaws, regulatory hurdles, business-as-usual bureaucracies and lack of leadership at multiple levels .... [T] he overall response by the government was too slow, especially when it came to logistical questions like getting enough testing supplies to those who needed them.").

104. See, e.g., Jason Horowitz, Italy's Health Care System Groans Under Coronavirus-A Warning to the World, N.Y. TIMES (Mar. 12, 2020), https://www.nytimes.com/2020/03/12 /world/europe/12italy-coronavirus-health-care.html.

105. Helen Branswell, Why "Flattening the Curve" may be the World's Best Bet to Slow the Coronavirus, STAT (Mar. 11, 2020). The now-ubiquitous phrase originated with a historical analysis of the 1918 pandemic and was endorsed in U.S. pandemic flu plans in 2007. See CTRS. FOR DISEASE Control \& Prevention, Interim Pre-Pandemic Planning Guidance 9 (2007). 
document titled "Implementation of Mitigation Strategies for Communities with Local COVID-19 Transmission." 106 The document was removed from the CDC website sometime later in the year. Described as "a framework for actions which local and state health departments can recommend in their community," the document advised that "actions should be guided by the local characteristics of disease transmission, demographics, and public health and healthcare system capacity."107 In places with "substantial" community transmission, defined as occurring when "healthcare staffing [is] significantly impacted [and there are] multiple cases within communal settings like healthcare facilities, schools, mass gatherings etc.," 108 the framework recommended that "[a]11 individuals should limit community movement and adapt to disruptions in routine activities (e.g., school and/or work closures) according to guidance from local officials." 109 The CDC framework additionally recommended that organizations should "cancel community and faith-based gatherings of any size." 110

The White House issued competing guidance on March 16. ${ }^{111}$ The "15 Days to Stop the Spread" guidelines recommended that certain groups - people who feel ill, people who test positive for coronavirus and their family members, and people who are older or who have serious underlying health conditions that put them at increased risk - should stay at home. It also recommended that everyone should "avoid social gatherings in groups of more than 10 people," "eating or drinking at bars, restaurants, and food courts," and "discretionary travel, shopping trips, and social visits." "112 With respect to closures, the guidelines noted that "[g]overnors in states with evidence of community transmission should close schools in affected and surrounding areas" and "[i]n states with evidence of community transmission, bars, restaurants, food courts, gyms, and other indoor and outdoor venues where groups of people congregate should be closed."113

In the latter half of March, state and local governments rapidly issued orders that exceeded what federal guidelines recommended. Lack of testing left leaders uncertain about whether substantial community transmission would soon overwhelm hospitals, prompting many to adopt the precautionary principle. ${ }^{114}$ The

106. Implementation of Mitigation Strategies for Communities, CTRS. FOR DiSEASE CONTROL \& PREVENTION (March 12, 2020) (on file with author).

107. Id. at 1.

108. Id. at 9.

109. Id. at 7.

110. Id.

111. 15 Days to Slow the Spread, White House (March 16, 2020), https://www.whitehouse.gov /articles/15-days-slow-spread/.

112. Id.

113. Id.

114. Branswell, supra note 105 (quoting Caitlin Rivers, an assistant professor of epidemiology at the Johns Hopkins Center for Health Security: "I think that in terms of the decision-makers, we are in a place right now where we don't have the data we wish we had in order to inform these 
same day the White House issued its 15 Days guidance, seven local health officers in the San Francisco Bay Area followed the examples set by China and Italy and issued mandatory shelter-in-place orders and prohibitions on all onsite business operations deemed nonessential. ${ }^{115}$ The orders indicated violations would be misdemeanor offenses punishable by fine, imprisonment, or both. Later, guidance issued to the San Francisco Police Department indicated that police may educate, admonish, seek voluntary compliance, and use enforcement for violations of the shelter-in-place order against businesses and individuals. ${ }^{116}$

The Bay Area orders opened the flood gates. Within two weeks, the majority of state governors had followed their lead. ${ }^{117}$ The details of orders varied. Nearly all states and many local governments closed schools and ordered bars, restaurants, theaters, gyms, shopping malls, and other settings where people tend to gather indoors to close or limit their operations. ${ }^{118}$ In a majority of jurisdictions, officials went further, closing all non-essential businesses to the public, with specified exceptions for health-care, food and agriculture, home repair, first responders, and other sectors deemed "essential" or "life-sustaining."119 Several jurisdictions followed the Bay Area Orders model by prohibiting all non-essential on-site business activities, even for facilities closed to the public. ${ }^{120}$ All states adopted limits on gatherings, though caps varied. ${ }^{121}$ Most governors also adopted statewide mandates for the general public to stay home except for essential work, errands, and some forms of outdoor exercise. Some state and local orders threatened violators with criminal penalties. Others relied on administrative sanctions and civil penalties, including citations, fines, and loss of business licenses. By the end of March, when the White House replaced its 15 Days guidance with "30 Days to Slow the Spread," ${ }^{22}$ the majority of states had gone

decisions, So what I think we're seeing is decision-makers struggling to pull the trigger on these really big, impactful decisions without having a clear sense of the current status.").

115. See, e.g., City \& CNTy. OF S.F. Admin. Order No. C19-07 (Mar. 16, 2020), https://sfgsa.org/sites/default/files/Document/OrderC19-07ShelterinPlace.pdf.

[https://perma.cc/QY48-MFZW]; Julia Prodis Sulek, Meet the Doctor Who Ordered the Bay Area's Coronavirus Lockdown, the First in the U.S., MERCURY News (Mar. 29, 2020, 3:55 PM), https://www.mercurynews.com/2020/03/29/she-shut-down-the-bay-area-to-slow-the-deadlycoronavirus-none-of-us-really-believed-we-would-do-it [https://perma.cc/K4DH-QYG8] (describing the events that led seven local jurisdictions to simultaneously issue shelter-in-place orders).

116. San Francisco Police Department, Notice 20-045: Enforcement of Public Health ORDERS (Mar. 23, 2020), https://www.sanfranciscopolice.org/sites/default/files/202003/SFPDNotice20.045.20200323.pdf.

117. Kates et al., supra note 87.

118. Id.

119. Id.

120. Id.

121. Id.

122. The President's Coronavirus Guidelines for America: 30 Days to Slow the Spread, WHITE 
significantly further than the White House or CDC guidance recommended.

In April, more states added stay-at-home orders and others issued extensions. ${ }^{123}$ Several state and local governments also issued mandatory face mask requirements, physical distancing requirements, and capacity or density limits to reduce the risk of transmission for essential workers and customers at essential businesses. ${ }^{124} \mathrm{CDC}$ reversed its earlier guidance directing that masks should only be worn by health workers and people who are sick. Later, this early guidance against masks for the general public would be widely reported as having been motivated by the need to conserve scarce supplies for health workers. But the mask guidance flip-flop was also driven by evolving understanding of the risk of asymptomatic or pre-symptomatic spread. Like social distancing, mask mandates for the general public were based on the need to treat everyone as if they could be silently spreading the virus to others.

Federal, state, and local governments also sought to provide supports and legal protections alongside the restrictions and mandates, but not nearly enough to meet dire needs. Many jurisdictions released some people in custody to de-densify congregate institutions. Many issued orders halting evictions and utility shutoffs. ${ }^{125}$ Some sought to provide financial support to businesses and households. Some removed regulatory barriers to open up more public space for safer alternatives to restricted activities. For example, many local governments closed streets to make more room for outdoor dining, exercise, and socializing. Congress passed two coronavirus response statutes: one on March $18^{126}$ and another on March 27. ${ }^{127}$ These bills provided important financial supports for businesses and some relief for households. But they did not prioritize the massive ramp-up of resources for testing, tracing, and supported isolation that would be required to

HousE (March 30, 2020), https://www.whitehouse.gov/wpcontent/uploads/2020/03 /03.16.20 coronavirus-guidance $8.5 \times 11$ 315PM.pdf.

123. Kates et al., supra note 87.

124. Id.

125. See, e.g., Office of the Mayor of San Francisco, Twelfth Supplement to Mayoral Proclamation Declaring the Existence of a Local Emergency Dated February 25, 2020 (Apr. 30, 2020), https://sfmayor.org/sites/default/files/Twelfth_Supplement 043020.pdf; Emily A. Benfer, Solomon J. Greene \& Margaret Hagan, Approaches to Eviction Prevention (Aug. 6, 2020) (unpublished manuscript) (available at https://papers.ssrn.com/sol3 /papers.cfm?abstract id $=3662736$ ). The $\mathrm{CDC}$ issued a federal eviction freeze order, relying on a provision in the Public Health Service Act that provides broad authority to federal health officials to adopt measures to control the spread of specific communicable diseases. Lindsay F. Wiley, CDC's Boundary-Pushing Eviction Freeze, ACS EXPERT FORUM (Sept 3, 2020), https://www.acslaw.org/expertforum/cdcs-boundary-pushing-eviction-freeze/. I will address the legal issues surrounding CDC's authority and potential reforms to the Public Health Service Act in a future project.

126. Families First Coronavirus Response Act, Pub. L. No. 116-127, 134 Stat. 178 (2020).

127. Coronavirus Aid, Relief, and Economic Security (CARES) Act, Pub. L. No. 116-136, 134 Stat. 281 (2020). 
implement a less disruptive approach to pandemic response.

\section{The Break-Down of Consensus: Resistance to Mitigation and Calls to "Crush the Curve" by Achieving Suppression}

By mid-April, lack of consensus about the strategic purpose of compulsory social distancing and shelter-in-place orders became painfully clear. Mitigation efforts had successfully prevented widespread community transmission from reaching many parts of the country, leaving their hospital capacity intact. ${ }^{128}$ The number of cases, hospitalizations, and deaths reported per day began to flatten and eventually decline at the national level. But national-level trends can be driven by large population centers like New York City and may not align with local conditions. A growing number of protestors demanded that stay-at-home orders be lifted and businesses be allowed to reopen since hospitals were not overwhelmed. ${ }^{129}$

Meanwhile, some commentators had begun calling for a more aggressive plan to "crush the curve." 130 Achieving long-term suppression of community transmission would save lives, minimize social disruption, and allow the economy to rebound more sustainably. Touting these benefits, some argued that stay at home orders and business closures should remain in place until human-to-human transmission was nearly eradicated. ${ }^{131}$ Experts offered detailed roadmaps, but these proposals depended on a massive and near-immediate expansion of capacity for easy-access testing. ${ }^{132}$ There was no indication that Congress would provide the

128. See Joel Rose, U.S. Field Hospitals Stand Down, Most Without Treating Any COVID-19 Patients, NATIONAl Public Radio (May 7, 2020), https://www.npr.org/2020/05/07/851712311/u-sfield-hospitals-stand-down-most-without-treating-any-covid-19-patients.

129. Charles Ornstein, How America's Hospitals Survived the First Wave of the Coronavirus, ProPubliCA (June 15, 2020), https://www.propublica.org/article/how-americas-hospitals-survivedthe-first-wave-of-the-coronavirus.

130. Joel Achenbach, As Social Distancing Shows Signs of Working, What's Next? Crush the Curve, Experts Say, WASH. PosT (April 8, 2020), https://www.washingtonpost.com/national/healthscience/as-social-distancing-shows-signs-of-working-whats-next-crush-the-curve-expertssay/2020/04/08/3c720e06-7923-11ea-b6ff-597f170df8f8 story.html.

131. Id. ("We should not end social distancing and reopen the economy until we know the infection rate is nearly zero .... "Aggressive mitigation measures, such as social distancing and the closure of nonessential businesses, should continue, even when the trend is moving in the right direction.").

132. E.g., Danielle Allen et Al., Roadmap to Pandemic Resilience: Massive Scale

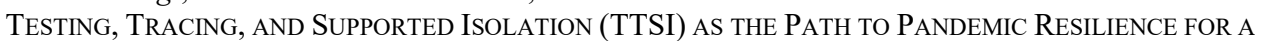
FREE SOCIETY (2020) (advocating for a massive scale-up of testing, tracing, and supported isolation to enable disease control while gradually easing social distancing restrictions); Harvey V. Fineberg, Ten Weeks to Crush the Curve, 382 NEw EnGL. J. MED. e37 (2020) (arguing that if the President established unified command to coordinate supply chains and ensure capacity to perform millions of diagnostic tests within two weeks, the U.S. could achieve lasting suppression within ten weeks). 
necessary funding any time soon. ${ }^{133}$ But "crush the curve" proponents were not always clear on the extent to which suppression required interventions other than social distancing, causing some to argue that if stay-at-home orders were kept in place just a little longer, sustainable suppression could be achieved. ${ }^{134}$

The influential March 16 Imperial College Task Force report had laid out the dilemma. Mitigation would flatten the curve but allow an unconscionable number of deaths over the course of the pandemic. ${ }^{135}$ Therefore, the reports authors determined that, "[f]or countries able to achieve it, this leaves suppression as the preferred policy option." ${ }^{136}$ The report defined suppression as "reduc[ing] the reproduction number (the average number of secondary cases each case generates), $\mathrm{R}$, to below 1 and hence ... reduc[ing] case numbers to low levels or (as for SARS or Ebola) eliminat[ing] human-to-human transmission."137 In addition to "social distancing of the entire population," this would require successful isolation and quarantine of infected and exposed individuals. ${ }^{138}$ The task force warned, however, that "this type of intensive intervention package ... will need to be maintained until a vaccine is widely distributed and accepted - given . . . that transmission will quickly rebound if interventions are relaxed." ${ }^{139}$ They suggested a third option, intermittent social distancing, could "allow interventions to be relaxed temporarily in relative short time windows," but warned that this approach would require a disease surveillance strategy to trigger re-tightening of restrictions in response to changing disease trends. ${ }^{140}$

Although the Imperial College Report that influenced U.S. lawmakers had laid out the available options in clear terms, elected officials issuing and renewing stayat-home orders were far from clear about which choice they were making. The White House guidelines - with their use of the phrase "slow the spread," and the lighter, more sustainable restrictions they recommended — appear to have adopted

133. See Emily Cochrane, Dispute Over Virus Testing Delays Deal on Aid to Small Businesses and Hospitals, N.Y. TIMES (Apr. 20, 2020), https://www.nytimes.com/2020/04/20 us/politics/congress-coronavirus-bill.html .

134. See, e.g., Bruce Lashan, Don't Flatten the Curve, Crush It, Doctors Urge Gov. Northam, WUSA9 (Apr. 27, 2020), https://www.wusa9.com/article/news/health/coronavirus/dont-flatten-thecurve-crush-it-end-coronavirus-network-urges-virginia-covid-19/65-31a13a56-82d1-452f-bbd8f815483260e8.

135. FERGUSON ET AL., supra note 3, at 1.

136. Id. (emphasis added).

137. Id. at 3. Some "crush the curve" proponents argued social distancing restrictions should be maintained at March levels until the reproduction level was zero. See Achenbach, supra note 130 ("Lee Riley, a University of California at Berkeley professor of infectious disease, said aggressive mitigation should continue long after the reproduction number drops below one. How long? 'I would say one month after you drive down the R naught to zero,' he said.").

138. Id. at 1.

139. Id. at 2.

140. $I d$. 
mitigation, rather than suppression, as the goal. The Bay Area Orders and the state orders that followed - with their stringent restrictions that no one could have imagined leaving in place for 18 months - appear to have been intended to buy time to deploy more targeted, testing-based strategies. In New York, Governor Cuomo referred to his order closing all nonessential businesses and prohibiting all gatherings of any size for any purpose other than essential work by the acronym "PAUSE," which suggested the restrictions would be able to achieve their purpose (described vaguely as "reduc[ing] the spread of this virus") within a matter of weeks, not months or years. ${ }^{141}$

By April 16, a month after the Bay Area Orders were issued, the President had lost patience with business closures and limits on gatherings. The White House released its "Guidelines for Opening Up America Again." The White House plan recommended a phased approach to resuming social gatherings and reopening schools and the types of businesses that the previous White House guidelines had recommended should be closed. ${ }^{142}$ Notably, there were no criteria for lifting mandatory orders to stay at home or reopening other nonessential businesses, since those measures had not been endorsed by the White House in the first place. The guidelines established "gating" criteria for reopening large venues and gyms after a sustained downward trajectory in the number of syndromic and reported cases for 14 days and at a point when hospitals are able to treat patients without resorting to crisis standards of care. Whether these criteria were based on a mitigation or suppression rationale was unstated. But a sustained downward trajectory in cases would appear to be consistent with suppression, making the plan quite cautious. The day after the reopening plan was released, the President tweeted that states must immediately "LIBERATE," fueling anti-lockdown protests. ${ }^{143}$

Crucially, the White House plan left states responsible for securing the infrastructure need to safely lift restrictions on high-risk settings. The guidelines defined testing, tracing, and disease surveillance as "core state preparedness

141. N.Y. Governor's Office, Governor Cuomo Signs the "New York State on PAUSE" Executive Order, STATE OF N.Y. (Mar. 20, 2020), https://www.governor.ny.gov/news/governorcuomo-signs-new-york-state-pause-executive-order.

142. President Donald J. Trump Announces Guidelines for Opening Up America Again, WhITE House (Apr. 16, 2020), https://www.whitehouse.gov/briefings-statements/president-donald-jtrump-announces-guidelines-opening-america; Guidelines: Opening Up America Again, WHITE HousE (April. 16, 2020), https://www.whitehouse.gov/openingamerica/; see also Michael D. Shear et al., Inside Trump's Failure: The Rush to Abandon Leadership Role on the Virus, N.Y. TIMES (July 18, 2020), https://www.nytimes.com/2020/07/18/us/politics/trump-coronavirus-response-failureleadership.html ("[White House aides'] ultimate goal was to shift responsibility for leading the fight against the pandemic from the White House to the states. They referred to this as "state authority handoff.").

143. Ben Collins and Brandy Zadronzy, In Trump's “LIBERATE” Tweets, Extremists See a Call to Arms, NBC NEws (Apr. 17, 2020), https://www.nbcnews.com/tech/security/trump-s-liberatetweets-extremists-see-call-arms-n1186561. 
responsibilities." ${ }^{144}$ President Trump repeatedly expressed skepticism regarding the wisdom of ramping up testing, arguing that "by doing all of this testing, we make ourselves look bad." "145 Later, when Congress considered legislation to provide federal funding for these needs, the President argued funding for testing should be zeroed out. ${ }^{146}$ Congressional negotiations repeatedly broke down and no new legislation was passed.

In May, many state and local governments eased restrictions as rapidly as they imposed them. All-or-nothing "light switch" thinking dominated the "reopen" phase, just as it had for the "lockdown" phase. Few officials referenced the likelihood that restrictions would need to be re-tightened in the future, suggesting they had rejected the Imperial College Task Force's intermittent social distancing strategy. Eventually, most states reopened bars, indoor dining at restaurants, gyms, and other higher-risk settings like movie theaters and bowling alleys in spite of the White House gating criteria not being met. Some jurisdictions maintained requirements for the general public to wear face masks and physically distance. ${ }^{147}$ To say there was no strategic plan would be an understatement.

In June, cases predictably surged in several places that had been largely spared during the spring. State and local governments began the first of multiple phases of re-tightening restrictions in an effort to "dial down" social mixing. In late June and July in the face of mounting case counts, state and local leaders unbundled social distancing into its distinct components and took a more nuanced approach to weighing the pros and cons of each intervention. ${ }^{148}$ Many more state and local governments issued face mask orders. ${ }^{149}$ Several re-tightened restrictions on large gatherings and re-closed bars and indoor dining. ${ }^{150}$ But the failure to clearly state

144. Id. (emphasis added).

145. Remarks by President Trump and Vice President Pence at a Meeting with Governor Reynolds of Iowa, WHITE HOUSE (May 6, 2020), https://www.whitehouse.gov/briefingsstatements/remarks-president-trump-vice-president-pence-meeting-governor-reynolds-iowa/.

146. Erica Werner \& Jeff Stein, Trump Administration Pushing to Block New Money for Testing, Tracing and CDC in Upcoming Coronavirus Relief Bill, WASH. PosT (July 18, 2020), https://www.washingtonpost.com/us-policy/2020/07/18/white-house-testing-budget-cdc-

coronavirus/.

147. See, e.g., Md. Exec. Order No. 20-04-15-01 (April 15, 2020) (requiring the general public to wear face coverings and maintain physical distance in retail establishments and on public transportation).

148. See, e.g., Ariz. Exec. Order No. 2020-43 (June 23, 2020) (imposing restrictions on "organized public gatherings" of more than 50 people and ordering bars, indoor fitness centers, indoor movie theaters, waterparks, and tubing operators to pause operations); Tex. Exec. Order No. GA-28 (June 26, 2020) (ordering bars to limit their service to carry-out, drive-through, or delivery only and closing rafting and tubing operators).

149. See, e.g., Kan. Exec. Order No. 20-52 (Jul. 2, 2020) (ordering the general public to wear face masks, subject to specified exceptions).

150. See e.g., Cal. Dep't of Pub. Health, Statewide Public Health Officer Order (July 13, 2020), https://www.cdph.ca.gov/Programs/CID/DCDC/CDPH\%20Document\%20Library 
the purpose of these orders (or the criteria by which their success would be judged) continued. And the likelihood of a nationally funded and coordinated testing and tracing system remained low. Given the utter abdication of responsibility by the President and the Senate majority, sparing hospitals from becoming overwhelmed was the most state and local governments could hope for in the second half of 2020 .

In late summer and early fall, many large institutions resumed face-to-face operations. Hundreds of thousands of travelers descended on the small city of Sturgis, South Dakota for its annual motorcycle rally, crowding into indoor bars. Many colleges and universities welcomed students back to campuses. In many states, pre-kindergarten through twelfth grade schools reopened with onsite classes. Reported cases began to grow exponentially in dozens of states, and hospital capacity was strained in many areas simultaneously, particularly in the Midwest.

Governors, mayors, and health officials took widely divergent approaches to the rise of the fall wave. Some local jurisdictions imposed tight restrictions that targeted particular neighborhoods or populations. In Boulder, Colorado, the county health department issued an order directing all residents of 37 specific addresses (known for housing Colorado University students) to stay at home with very narrow exceptions and prohibiting gatherings for 18- to 22-year-olds. ${ }^{151}$ Mayor Bill DeBlasio, with approval from Governor Andrew Cuomo, closed schools and all non-essential businesses in nine New York City zip codes where test-positivity rates were creeping upwards. ${ }^{152}$ Many other officials openly embraced a hands-off approach, arguing that wearing a mask and avoiding crowds should be matters of personal choice, rather than government control. After being diagnosed with COVID-19 himself, President Trump advised the American people not to fear the virus and not to let it control their lives. ${ }^{153}$

Shortly after the 2020 election, a task force convened by President-Elect Joe Biden began promoting a more nuanced approach to compulsory social distancing. The task force indicated the President-Elect would work with state and local governments to implement a scaled, intermittent approach to social distancing.

/COVID-19/SHO\%20Order\%20Dimming\%20Entire\%20State\%207-13-2020.pdf (closing bars and indoor restaurant service).

151. Boulder Cty. Pub. Health, Amended Public Health Order 2020-07-03 (Sept. 28, 2020), https://assets.bouldercounty.org/wp-content/uploads/2020/09/pho-2020-07-09232020.pdf.

152. Mayor de Blasio Sends State Proposal to Close Schools and Non-Essential Businesses in Nine New York City Zip Codes, STATE OF N.Y. (Oct. 4, 2020), https://www1.nyc.gov/office-of-themayor/news/693-20/mayor-de-blasio-sends-state-proposal-close-schools-non-essential-businessesnine-new-york\#/0.

153. Gina Kolata \& Roni Caryn Rabin, “Don't be Afraid of Covid,” Trump Says, Undermining Public Health Messages, N.Y. TIMEs (Oct. 8, 2020), https://www.nytimes.com/2020/10/05 health/trump-covid-public-health.html. 
Their report also said he would work with Congress to provide financial support for businesses, households, and public health infrastructure. ${ }^{154}$

By the end of the year, several governors and mayors were tightening restrictions in response to local conditions. ${ }^{155}$ Some hesitated to restrict indoor restaurant service or close any businesses even while imposing harsh limits on social gatherings. ${ }^{156}$ Others doubled-down on their refusal to take the pandemic seriously. Even as South Dakota's per-capita death rate emerged as one of the highest in the world, Governor Kristi Noem criticized restrictions and warnings issued by other leaders, promising "We won't stop or discourage you from thanking God and spending time together this Thanksgiving." 157

\section{COMMUNITY MITIGATION IN THE COURTS}

Due to the unprecedented nature of the coronavirus pandemic, the widespread and deeply intrusive measures adopted by most states and many local jurisdictions in the spring of 2020 were largely untested - scientifically or legally. Experts anticipated benefits based on modeling and planning exercises developed in preparation for a novel influenza pandemic ${ }^{158}$ — and limited studies of measures implemented in mainland China, Hong Kong, and other places across the globe ${ }^{159}$ - but ongoing research and surveillance were needed to assess these measures in real time. By the end of March 2020, churches, business owners, and private individuals had filed a handful of lawsuits challenging gathering bans, restrictions on places of worship, restrictions on businesses, travel restrictions, and orders to

\footnotetext{
154. Priorities: COVID-19, Biden-Harris Transition (Nov. 11, 2020), https://buildbackbetter.com/priorities/covid-19/.
}

155. See, e.g., N.M. DePt. Pub. Health., Public Health Order Re COVID-19 (Nov. 13, 2020) (prohibiting all nonessential onsite business operations and all gatherings of people from two or more households and limiting restaurants to carry-out service); Ky. Exec. Order No. 2020-968 (Nov. 18, 2020) (closing bars and indoor dining and limiting "indoor social gatherings" to no more than 8 people from no more than 2 households); Minn. Exec. Order No. 20-99 (Nov. 17, 2020) (closing bars, fitness centers, and other indoor gathering places and prohibiting indoor dining and all gatherings of people from more than one household, whether indoors or outdoors).

156. See, e.g., R.I. Exec. Order No. 20-98 (Nov. 19, 2020), https://governor.ri.gov/documents/orders/Executive-Order-20-98.pdf. (prohibiting all gatherings of people from more than one household - whether indoors or outdoors - unless a professional caterer is hired or the event is held at a restaurant, in which case up to 25 (indoors) or 75 (outdoors) attendees are permitted).

157. South Dakota's Kristi Noem Among Governors Ignoring CDC Advice On Thanksgiving Gatherings, CBS MinNESOTA (Nov. 21, 2020), https://minnesota.cbslocal.com/2020/11/21/southdakota-gov-kristi-noem-ignores-cdc-advice-on-thanksgiving-gatherings/.

158. See, e.g., Glass et al., supra note 1; QuALLS ET AL., supra note 70.

159. See, e.g., Kylie E. C. Ainslie et Al., Imperial College COVID-19 Response Team Report 11: Evidence of Initial Success for China Exiting Social Distancing Policy After ACHIEVING CONTAINMENT 2 (2020), https://www.imperial.ac.uk/mrc-global-infectious-diseaseanalysis/covid-19/report-11-china-exiting-social-distancing/. 
shelter in place. Many more lawsuits followed in the weeks and months of restrictions that followed. Lawsuits were brought by public health authorities seeking judicial enforcement of coronavirus mitigation measures, ${ }^{160}$ by advocates seeking release of people in custody to protect them from unsanitary conditions, ${ }^{161}$ by state authorities asserting their preemption of local power to issue and enforce emergency orders, ${ }^{162}$ by landlords seeking to overturn eviction freezes, ${ }^{163}$ and by state legislatures and individual legislators asking courts to lift or modify restrictions. As consensus broke down and many leaders implemented scaled responses, business owners and religious groups challenged distinctions among various types of services, businesses, and activities, arguing they were arbitrary and discriminated on the basis of religion. ${ }^{164}$

Restrictions and mandates for social distancing purposes raise a wide range of legal issues. Plaintiffs have argued that restrictions violate their individual rights under the First Amendment, Second Amendment, and the Fourteenth Amendment's procedural due process, substantive due process, equal protection, and regulatory takings doctrines. ${ }^{165}$ They have also relied on state constitutional and statutory protections for individual rights. State-law limits on administrative discretion derived from constitutional separation of powers doctrines have posed

160. See, e.g., Larimer County Public Health v. Maniacs Gym, LLC, 2020 WL 1943829 (Colo. Dist. Ct. Apr. 1, 2020) (granting a preliminary injunction ordering the defendant to cease business operations in violation of a public health order issued by the county public health director ordering gymnasiums to close); St. Louis Cty. v. House of Pain Gym Servs., 4:20CV655 RLW, 2020 WL 2615746 (E.D. Mo. May 22, 2020) (denying defendant gyms' motion to dismiss a common law nuisance claim brought by the county to enforce its health officer's stay-at-home order, which the defendants had removed to federal court).

161. Health is Justice: COVID-19 Decarceration Decision Spreadsheet (last updated Aug. 5, 2020), https://docs.google.com/spreadsheets/d/1L 1VGAf-G1VRgi7a pFhkTNPRi89MfMjT9E Gjxiac/edit\#gid=393515537 (compilation of hundreds of decarceration suits by the Columbia University Health is Justice Initiative).

162. See, e.g., Greg Bluestein \& Jeremy Redmon, Judge Orders Mediation in Georgia's Mask Mandate Lawsuit, ATLANTA J.-CONST. (July 23, 2020), https:/www.ajc.com/politics/politicsblog/bottoms-kemp-discuss-settlement-in-georgias-mask-mandate-

lawsuit/ACJP3ANHHRDOZFAMNLSKIX5GW4/. As they define the scope of state executive power, state legislatures should determine the extent to which state executive-branch officials are empowered to preempt local authority to respond to a public health emergency. Arguments that state laws should not preempt local measures that are more protective of public health are consistent with my arguments for statutory guardrails that emphasize transparency and accountability alongside protections for individual rights, but preemption raises distinct issues that are beyond the scope of this article. See, e.g., Kim Haddow, Derek Carr, Benjamin D. Winig \& Sabrina Adler, Preemption, Public Health, and Equity in the Time of COVID-19, in BURRIS, ET AL., supra note 4 ("State governments should permanently remove state preemption of more protective local laws related to COVID-19 response.").

163. See, e.g., Baptiste v. Kennealy, 1:20-CV-11335-MLW, 2020 WL 5751572 (D. Mass. Sept. $25,2020)$.

164. See Part III.B and C infra.

165. Id. 
particularly thorny challenges for executive orders. None of these constraints imposes an absolute limit on government intervention. Protections for individual rights are balanced against government interests. Separation of powers doctrines are loosely defined and rarely deployed as hard limits. Ultimately, the courts have had considerable discretion to shape their own role in pandemic response. The vast majority of challenges to social distancing and face mask orders have failed.

For my purposes, five themes running through the judicial opinions reviewing coronavirus mitigation measures from March through November 2020 are important: First, many courts have adopted highly deferential "emergency" standards of review, which a majority of the Supreme Court now appears to disfavor, muddling judicial guidance to the legislatures. Second, judges have enjoined enforcement of some mitigation measures that infringe on fundamental rights, particularly those that discriminate on the basis of religion. Third, for the most part, judges have asked whether emergency orders are arbitrary or capricious and have occasionally found that distinctions among businesses and activities fail this lenient standard. Fourth, many courts have found that coronavirus community mitigation measures do not fit within specific statutory delegations of authority, but most have upheld orders as a valid exercise of more broadly defined authorities Fifth, disputes over the boundary between executive and legislative authority have played a prominent role in challenges to coronavirus emergency orders, but most courts have upheld broad delegations. Legislatures in some states appear eager to weigh in on the next steps in the coronavirus pandemic response, but the judiciary has, for the most part, indicated that the courts are not the appropriate venue for them to do so.

\section{A. Emergency Standards of Judicial Review}

Several courts adjudicating coronavirus civil liberties challenges have grappled with what Professor Stephen Vladeck and I have described as "the central (and long-running) normative debate over emergency powers: Should constitutional constraints on government action be suspended in times of emergency (because emergencies are 'extraconstitutional'), or do constitutional doctrines forged in calmer times adequately accommodate exigent circumstances?"166 In early April, the Fifth Circuit "reduced" the complex 1905 Supreme Court decision in Jacobson v. Massachusetts to "a clear and easy test" dictating suspension of ordinary, heightened standards of review for measures that infringe upon civil liberties during a public health emergency. ${ }^{167}$ Quoting

166. Wiley \& Vladeck, COVID-19 Reinforces the Argument for "Regular" Judicial ReviewNot Suspension of Civil Liberties-In Times of Crisis, supra note 8.

167. Parmet, supra note 39, at 131; In re Abbott, 954 F.3d 772 (5th Cir. 2020). Cf. Binford v. Sununu, No. 217-2020-CV-00152 (N.H. Super. Ct. Mar. 25, 2020) (relying on Smith v. Avino, 91 
Jacobson, In re Abbott held that "when faced with a society-threatening epidemic, a state may implement emergency measures that curtail constitutional rights so long as the measures have at least some 'real or substantial relation' to the public health crisis and are not 'beyond all question, a plain, palpable invasion of rights secured by the fundamental law." "168 Several courts followed the Fifth Circuit, adopting the highly deferential "plain, palpable violation" language as the definitive standard of review for public health emergency orders. ${ }^{169}$ For ease of reference, I refer to this as the Jacobson suspension doctrine.

In November, the Supreme Court applied strict scrutiny to enjoin occupancy limits for houses of worship. ${ }^{170}$ The application of strict scrutiny in Roman Catholic Diocese of Brooklyn v. Cuomo appears to indicate that a majority of the Court rejects the Jacobson suspension doctrine, at least as applied to claims of religious discrimination. It is not clear, however, whether a majority of the Court might support the Jacobson suspension doctrine if another right — such as the right to choose an abortion or the right to travel—were at issue. Four justices (Justices Samuel Alito, Brett Kavanaugh, Clarence Thomas, and Neil Gorsuch) have signed opinions expressly opposing the Jacobson suspension doctrine for First Amendment challenges to emergency orders. ${ }^{171}$ One of them, Kavanaugh, has

F.3d 105, 109 (11th Cir. 1996) to hold that usual, heightened scrutiny of state laws interfering with civil liberties should be "suspended" for the duration of an emergency and adopting a good faith/some factual basis test to uphold an emergency order limiting gatherings to fewer than 50 people).

168. Id. at 784 .

169. See, e.g., In re Rutledge, 956 F.3d 1018, 1027 (8th Cir. 2020) (holding that the district court abused its discretion by failing to apply the Jacobson standard to an emergency restriction on abortion); but see Robinson v. Att'y Gen., 957 F.3d 1171, 1181 (11th Cir. 2020) (holding that the district court did not err in reading Jacobson and Smith in light of Casey and concluding that the burdens imposed by emergency restrictions on abortion were undue under Casey, and that they impinged the right to an abortion in a "plain, palpable" fashion under Jacobson). Public health and constitutional scholars have argued that the highly deferential way in which many courts have applied Jacobson's language in 2020 does not comport with how the courts of the time would have understood it. See, e.g., Wiley \& Vladeck, supra note 8, at 191 (arguing that the Supreme Court's reference to what was "reasonable" in Jacobson was far more robust than what we tend to think of today as "minimum rationality" rational basis review); Parmet, supra note 39, at 131 (arguing that Jacobson "offered a mélange of criteria for when courts should intervene (unreasonable, oppressive, plain and palpable invasions of rights)," not the "clear and easy test" that many courts in 2020 have "reduced" it to); Blackman, supra note 43, at 43 (arguing that the standard of review adopted in Jacobson "did not resemble the modern rational basis test - even where the Supreme Court referred to a 'rational' basis").

170. Roman Catholic Diocese of Brooklyn v. Cuomo, 141 S. Ct. 63 (2020); see also part III.B. and Part IV.C, infra.

171. In July, Justice Alito explicitly discussed the Jacobson suspension doctrine in his dissent from a decision denying a Nevada church's request for injunctive relief. Writing for himself, Kavanaugh, and Thomas, Alito argued "it is a mistake to take language in Jacobson as the last word on what the Constitution allows public officials to do during the COVID-19 pandemic." Calvary Chapel Dayton Valley v. Sisolak, 140 S. Ct. 2603, 2608 (Alito, J., dissenting). It is worth noting, however, that Alito's dissent drew a distinction between substantive due process claims and First 
indicated that he might hold a different view of the judiciary's role, at least when voting rights are at issue. ${ }^{172}$ In that context, Kavanaugh endorsed "a limited role of the federal courts in COVID-19 cases." ${ }^{173}$ Justices Stephen Breyer, Elena Kagan, and Sonia Sotomayor appear to agree with Chief Justice Roberts "that courts must grant elected officials 'broad' discretion when they 'undertake to act in areas fraught with medical and scientific uncertainties." "174 Three justices (Breyer, Kagan, and Sotomayor) have specifically praised a lower court judge for "declin[ing] to second guess the State's judgment about what should qualify as an essential business." 175 No justices have expressly endorsed the Jacobson suspension doctrine, however. ${ }^{176}$

Ongoing uncertainty over the validity of the Jacobson suspension doctrine

Amendment claims. $I d$. (describing Jacobson as involving "a substantive due process challenge to a local ordinance requiring residents to be vaccinated for small pox" and contrasting that with "statewide measures of indefinite duration... challenged under the First Amendment or other provisions not at issue in [Jacobson]."). The reference to "other provisions" could also encompass Second Amendment challenges. In Catholic Diocese, Gorsuch wrote a concurring opinion eviscerating the Jacobson suspension doctrine. Roman Catholic Diocese (Gorsuch, J., concurring) (arguing "Jacobson didn't seek to depart from normal legal rules during a pandemic, and it supplies no precedent for doing so"). Gorsuch also carved out a possible exception for substantive due process claims, however. Id. (using scare quotes to refer to Jacobson's adjudication of a "'substantive due process' right to 'bodily integrity" and arguing that "[e]ven if judges may impose emergency restrictions on rights that some of them have found hiding in the Constitution's penumbras, it does not follow that the same fate should befall the textually explicit right to religious exercise").

172. In Democratic National Committee v. Wis. State Legislature, 141 S. Ct. 28 (Oct. 26, 2020) (Kavanaugh, J., concurring) (mem.), Kavanaugh quoted Roberts's quotation of Jacobson (though without attribution to either) in support of his argument that refusing to stay a lower court order enjoining limits on mail-in voting was inconsistent with "the limited role of the federal courts in COVID-19 cases." Id; compare id. ("This Court has consistently stated that the Constitution principally entrusts politically accountable state legislatures, not unelected federal judges, with the responsibility to address the health and safety of the people during the COVID-19 pandemic.") with South Bay United Pentecostal Church v. Newsom, 140 S. Ct. 1613, 1613 (Roberts, C.J., concurring) (quoting Jacobson 197 U.S. 11, 28 (1905) ("Our Constitution principally entrusts ' $[t]$ he safety and the health of the people' to the politically accountable officials of the States 'to guard and protect.'”).

173. Democratic National Committee, 141 S. Ct. 28 (Kavanaugh, J. concurring).

174. Roman Catholic Diocese of Brooklyn v. Cuomo, 141 S. Ct. 63, 78 (2020) (Breyer, J. dissenting) (quoting S. Bay United Pentacostal Church v. Newsom, 140 S. Ct. 1613, 1613 (Roberts, C.J., concurring)).

175. Id.

176. Roberts has twice relied on Jacobson for what he describes as the "uncontroversial" proposition that "[o]ur Constitution principally entrusts ' $[\mathrm{t}]$ he safety and the health of the people' to the politically accountable officials of the States 'to guard and protect." Catholic Diocese (Roberts, C.J., dissenting) (quoting S. Bay United Pentacostal Church v. Newsom, 140 S. Ct. 1613, 1613 (Roberts, C.J., concurring)). However, in Catholic Diocese, he clarified that his citation to Jacobson should not be interpreted as an endorsement of the Jacobson suspension doctrine. Id. Moreover, Roberts refuted Gorsuch's characterization of the other dissenting justices (Breyer, Sotomayor, and Kagan) as "'cutting the Constitution loose during a pandemic,' yielding to 'a particular judicial impulse to stay out of the way in times of crisis,' or 'shelter[ing] in place when the Constitution is under attack."” Id. (quoting id. (Gorsuch, J., concurring)). 
makes it more difficult for state legislatures to draw lessons from coronavirus court orders. Indeed, this is one of the arguments Vladeck and I made against the suspension principle. ${ }^{177}$ It is now clear that pre-November cases applying the Jacobson suspension standard to orders that discriminate against religious institutions are not valid precedents. Whether other pre-November precedents relying on suspension remain valid is open to debate. Several courts have applied ordinary standards of review, however, and even decisions that have adopted a more deferential stance offer some guidance. Even before Roman Catholic Diocese, some courts rejected the suspension principle outright, but found that mitigation measures were likely to satisfy ordinary standards of review, including intermediate and strict scrutiny. ${ }^{178}$ Some lower courts wisely applied both the Jacobson suspension standard and the ordinary standard, and determined that challenged orders were likely to be upheld either way. Perhaps the key lesson of the Jacobson suspension doctrine for state legislatures is that they should provide statutory protections, rather than depending on judicial activism, to define the boundaries of executive authority in a public health emergency.

\section{B. Government Action that Infringes on Fundamental Rights}

Criticism of the extent to which fundamental civil liberties have been limited in response to the 2020 coronavirus pandemic was initially confined to a small minority of staunch advocates. Even the American Civil Liberties Union (ACLU) has been hesitant to weigh in on social distancing. ACLU's initial press release cautioned that "[a]s the government takes the necessary steps to ensure public health, it must also safeguard people's due process, privacy, and equal protection rights." 179 As the pandemic continued, however, and as it became clear that the public broadly supported compulsory social distancing and mask mandates, ACLU stepped back from scrutinizing these measures, preferring instead to focus on securing release of people from crowded institutions, advocating against

177. See Wiley \& Vladeck, supra note 8, at 194-97.

178. See, e.g., Bayley's Campground Inc. v. Mills, 463 F.Supp. 3d 22 (D. Me. 2020) (finding that restrictions on travelers and temporary lodgings are likely to satisfy strict scrutiny review because no less restrictive alternative was available to the state given lack of access to virus testing); Henry v. DeSantis, 461 F.Supp. 3d 1244, at 1254-55 (S.D. Fla. 2020) (upholding stay-at-home order after finding that rights to associate for purely social purposes do not trigger heightened scrutiny under the First Amendment and that the plaintiff's Fourteenth Amendment claims did not trigger intermediate or strict scrutiny because she did not properly allege a suspect classification or infringement of a fundamental right); Minnesota Voters Alliance v. Walz, No. 20-CV-1688, 2020 WL 5869425 (D. Minn. Oct. 2, 2020) (finding that a face-mask order was likely to withstand intermediate scrutiny, without determining whether intermediate scrutiny was required).

179. ACLU Comment on COVID-19 Emergency Declaration, AM. CIV. LIBERTIES UnION (Mar. 13, 2020), https://www.aclu.org/press-releases/aclu-comment-covid-19-emergency-declaration. 
coronavirus abortion restrictions, and expanding access to mail-in voting. ${ }^{180}$ Some governors responded flippantly to questions about the balance between public health and fundamental rights. In mid-April, New Jersey Governor Phil Murphy told Fox News host Tucker Carlson he "wasn't thinking of the Bill of Rights" when he issued his stay-at-home order because the constitutionality of the orders was "above [his] pay grade." "181

Businesses connected to constitutionally protected fundamental rights brought some of the first coronavirus civil liberties challenges. In the first opinion from a state's highest court, the Supreme Court of Pennsylvania rejected a preliminary injunction request by the owner of a gun shop deemed nonessential and an individual seeking to buy a firearm, arguing the closure violated the right to bear arms. ${ }^{182}$ Swayed by the dissenting justices, however, the governor quietly exempted gun shops. ${ }^{183}$ Firearms dealers and gun ranges have argued limits on their operation infringe upon the Second Amendment right to bear arms as well as state statutory provisions protecting gun rights. ${ }^{184}$ Another early group of suits challenged restrictions on abortion implemented in the name of preserving health care capacity. ${ }^{185}$ Each of these groups of cases have been addressed in law review articles that drill down into the specific issues they raise. ${ }^{186}$ I address them briefly here to highlight how they fit into the bigger picture of the emerging law of social distancing.

First Amendment rights to freedom of religion, assembly, association, and expression have played a predictably prominent role in coronavirus civil liberties

180. David Cole, Civil Liberties Never Sleep: The ACLU in the Pandemic, AM. CIV. LiberTIES UNION (Apr. 10, 2020), https://www.aclu.org/news/civil-liberties/civil-liberties-never-sleep-theaclu-in-the-pandemic/. I will withhold comment on these issues, which will certainly be addressed by election law experts.

181. Katherine Timpf, The Bill of Rights is Not “Above” Any Government Leader's "Pay Grade”, NAT'L REV. (Apr. 16, 2020), https://www.nationalreview.com/2020/04/the-bill-of-rights-isnot-above-any-government-leaders-pay-grade/.

182. Civil Rights Defense Firm v. Wolf, Civ. No. 63 MM 2020 (Pa. Mar. 22, 2020).

183. Marc Levy et al., Wolf Reopens Gun Shops, Orders More Residents to Stay Home, AsSOCIATED PRESS (Mar. 24, 2020), https://apnews.com/d8dde6f12ec1d238da2db09375d8e84f.

184. See, e.g., Lynchburg Range \& Training, LLC v. Northam, 2020 WL 2073703 (Apr. 27, 2020) (citing federal and state constitutional rights to bear arms and a Virginia statute providing that the state's emergency law "is not to be construed to ... [e]mpower the Governor, any political subdivision, or any other governmental authority to in any way limit or prohibit the rights of the people to keep and bear arms ...."); see also Altman v. County of Santa Clara, 2020 WL 2850291 (N.D. Calif. June 2, 2020).

185. See, e.g., Aziza Ahmed, How the COVID-19 Response is Altering the Legal and Regulatory Landscape on Abortion, 7 J. L. \& BIOSCIENCES 1 (2020).

186. See, e.g., B. Jessie Hill, Essentially Elective: The Law and Ideology of Restricting Abortion During the COVID-19 Pandemic, 106 VA. L. REV. OnLINE 99 (2020); Blackman, supra note 43; Joyce Lee Malcolm, Self Defense, an Unalienable Right in a Time of Peril: Protected and Preserved by the Second Amendment, LiBerTy \& LAW CENTER Research Paper No. 20-02 (draft dated Oct. 14, 2020), https://papers.ssrn.com/sol3/papers.cfm?abstract_id=3703895. 
litigation, but aside from freedom of religion, these claims have largely been rejected by the courts. The cases on religious liberty will certainly generate a rich literature of their own. ${ }^{187}$ I address them briefly here only to note that the key issue has been the extent to which orders discriminate on the basis of religion or, alternatively, are neutral laws of general applicability. A generally applicable law that imposes incidental burdens on religious practices is subject to rational basis review under current Supreme Court precedent, ${ }^{188}$ while a law that discriminates against religious practices must withstand strict scrutiny. ${ }^{189}$ In South Bay United Pentecostal Church v. Newsom, Chief Justice Roberts offered a clear path forward for state and local orders restricting religious services. Roberts emphasized the nondiscriminatory nature of the challenged executive orders in light of "similar or more severe restrictions on comparable secular gatherings" like theaters and concerts. ${ }^{190}$ But following the appointment of Justice Amy Coney Barrett to the Court, the majority now sees things differently. In Catholic Diocese, the Court followed several lower court judges in comparing gatherings at places of worship to spontaneous collections of shoppers in retail settings, including liquor stores. ${ }^{191}$ As the Western District of Kentucky put it in one of several cases enjoining enforcement of restrictions against holiday church services: "if beer is essential, so is Easter." 192 Under Catholic Diocese, orders that "single out houses of worship" for restrictions that do not apply to other settings - including commercial establishments, factories, and public services deemed "essential" — will be subjected to strict scrutiny. ${ }^{193}$

In Ramsek v. Beshear, the Eastern District of Kentucky offered a rare rebuke of a state gathering ban on freedom-of-assembly grounds, holding that "a blanket prohibition on gathering in large groups to express constitutionally protected speech is unconstitutional. When liberty is at stake, policy makers must be more precise."194 The plaintiffs were residents who opposed the governor's orders and

187. See, e.g., Blackman, supra note 43; Caroline Mala Corbin, Religious Liberty in a Pandemic, 70 DuKE L.J. ONLINE 1 (2020).

188. Emp't Div., Dep't of Human Res. of Or. v. Smith, 494 U.S. 872, 878-79 (1990).

189. Church of the Lukumi Babalu Aye, Inc. v. City of Hialeah, 508 U.S. 520,553 (1993).

190. 140 S. Ct. 1613, 1613 (2020) (denying application for injunctive relief) (Roberts, C.J., concurring)

191. Roman Catholic Diocese of Brooklyn v. Cuomo, 141 S. Ct. 63 (2020); see also S. Bay, 140 S. Ct. 1613 at 1614 (Kavanaugh, J., dissenting).

192. On Fire Christian Ctr., Inc. v. Fischer, 2020 WL 1820249 (W.D. Ky. April 11, 2020).

193. Roman Catholic Diocese of Brooklyn v. Cuomo, 141 S. Ct. 63 (2020). Whether lighter restrictions for schools or essential factories would be permissible was not addressed in the case in detail, but the majority did describe schools and factories as having "contributed to the spread of COVID-19" and being "treated less harshly" than the plaintiffs. In reality, however, the challenged order directed local health departments to close schools. N.Y. Exec. Order No. 202.68 (Oct. 6, 2020).

194. Ramsek v. Beshear, 2020 WL $3446249 * 1$ (E.D. Ky. June 24, 2020). 
wished "to express their views through protesting." "195 Suggesting that "expressive conduct - such as gathering - in a public forum" is a form of protected speech, the judge enjoined state officials "from enforcing the prohibition on mass gatherings as it relates to in-person, political protests." 196 The court found the gathering ban to be a content-neutral time, place, and manner restriction and applied intermediate scrutiny. Ultimately, the court found the ban failed the intermediate scrutiny test because there were less restrictive alternatives available to accomplish the governor's purposes: "Clearly, policymakers have some tools at their disposal which will help mitigate the spread of coronavirus while still allowing Kentuckians to exercise their First Amendment freedoms.... $[\mathrm{M}]$ aintaining a social distance of six feet, wearing masks, and frequent and thorough handwashing each help to reduce the likelihood of transmission of coronavirus from person to person. The Commonwealth has required implementation of these tools in places like restaurants, office buildings, and auctions, but continues to wholly prohibit gatherings for political protest above a set number no matter the circumstance." 197

Other courts have rejected First Amendment claims. In Geller v. de Blasio, for example, a plaintiff who planned to organize a gathering to protest coronavirus executive orders brought suit seeking to enjoin the city from enforcing a ban on non-essential gatherings of any size. ${ }^{198}$ The Southern District of New York applied intermediate scrutiny, but found the order was reasonable and narrowly tailored and therefore the plaintiff was unlikely to succeed on the merits. ${ }^{199}$ In Henry $v$. DeSantis, the Southern District of Florida rejected the First Amendment claims of a plaintiff who did not have specific plans to engage in political protests on the grounds that " $[\mathrm{t}]$ the Supreme Court has not found a generalized right of social association under the First Amendment's freedom of association." 200 The Eastern District of California reached a similar conclusion in a freedom-of-association claim brought by a fitness center, which argued that "[w]hen ... staff and customers interact, they engage in expressive association and the advancement of

195. Id.

196. Id.

197. Id. at *10.

198. Geller v. de Blasio, 2020 WL $2520711 * 3-* 4$ (S.D.N.Y. 2020); accord McCarthy v. Cuomo, 2020 WL 3286530, *4 (E.D.N.Y.); accord SH3 Health Consulting, LLC v. Page, 2020 WL 2308444 (E.D. Mo. May 8, 2020); accord Benner v. Wolf, 2020 WL 2564920 (M.D. Pa. May 21, 2020).

199. Geller v. de Blasio, 2020 WL $2520711 * 3-* 4$. Other courts have upheld restrictions on political protests after adopting the Jacobson suspension standard (see, e.g., SH3 Health Consulting, 2020 WL 2308444, at*12), but the precedential value of these cases after Roman Catholic Diocese is in doubt.

200. Henry v. DeSantis, 461 F.Supp. 3d 1244, 1254 (S.D. Fla. 2020) (citing City of Dallas v. Stanglin, 490 U.S. 19, 25 (1989) (internal quotation marks omitted). 
shared beliefs." 201 The court noted the lack of precedents "support[ing] the idea that the freedom to associate is designed to protect this type of non-expressive, commercial interaction." 202

Challenges to face mask orders on First Amendment grounds have been unsuccessful. In an early case, Antietam Battlefield KOA v. Hogan, ${ }^{203}$ the plaintiffs argued that being required to wear face masks amounted to compelled expressive conduct. Finding that "requirements for face coverings . . . reduce the chance that respiratory droplets containing the virus will infect others," the Maryland federal district court found that the order satisfied the Jacobson suspension standard of review. In a later case, Minnesota Voters Alliance v. Walz, a different federal district court held that "even if wearing or not wearing a face covering was inherently expressive, [the governor's face mask order] is clearly constitutional, whether analyzed under [an intermediate scrutiny standard that would ordinarily apply to some types of regulations of expressive conduct] or Jacobson." ${ }^{204}$ In doing so, the court found that "federal health officials recommend face coverings as an effective way to slow the spread of COVID-19, and this recommendation finds support in recent studies." 205

Several coronavirus plaintiffs have argued that restrictions on their business operations amounted to uncompensated regulatory takings in violation of the Fifth Amendment (incorporated to the states via the Fourteenth Amendment) or similar provisions found in state constitutions. Thus far, the courts have uniformly rejected this argument. ${ }^{206}$ As a federal district judge held in McCarthy v. Cuomo, restrictions on certain types of businesses "do not deny [business owners] all economically beneficial use of [their] property" because they could alter their business operations to provide services deemed essential. ${ }^{207}$

Thus far, few courts have clearly identified the Fourteenth Amendment

201. Best Supplement Guide, LLC v. Newsom, No. 2:20-cv-00965-JAM-CKD, 2020 WL 2615022 at $* 4$ (E.D. Cal. May 22, 2020).

202. Id.

203. 461 F. Supp. 3d 214 (D. Md. 2020).

204. Minnesota Voters Alliance v. Walz, No. 20-CV-1688, 2020 WL 5869425 (D. Minn. Oct. 2, 2020).

205. In past crises, judges have frequently relied on guidelines from CDC or the WHO when assessing the best available scientific evidence. The lack of consistent guidelines from CDC regarding social distancing in 2020 and the fact that the White House released conflicting guidelines may have played a role in some judges' decisions to embrace a suspension standard of review. See Lindsay F. Wiley, Public Health Law and Science in the Community Mitigation Strategy for Covid19, 7 J. L. \& BIOSCIENCES lsaa019 (2020).

206. See, e.g., Lawrence v. Colorado, No. 1:20-cv-00862-DDD-SKC, 2020 WL 2737811 (D. Colo April 19, 2020) ("temporary moratoria on various business activities . . . are not compensable takings"); accord Friends of Danny DeVito v. Wolf, 227 A.3d 872, 881 (Pa. 2020).

207. See, e.g., McCarthy v. Cuomo, 2020 WL 3286530, *5 (E.D.N.Y. 2020). 
substantive due process rights implicated by coronavirus emergency measures, ${ }^{208}$ and even fewer have found community mitigation measures to run afoul of them. In Roberts v. Neace, the Eastern District of Kentucky enjoined enforcement of the governor's restrictions on out-of-state travel, finding that the restrictions infringed upon rights protected by substantive due process and would probably fail the strict scrutiny test because they were not narrowly tailored to serve a compelling state interest. ${ }^{209}$ In Bayley's Campground Inc. v. Mills, however, the federal district court for Maine upheld even more stringent travel restrictions. The court applied strict scrutiny to a 14-day quarantine on those entering from out-of-state, coupled with a prohibition on rental of temporary lodgings to people who had not yet completed their quarantine within the state of Maine. ${ }^{210}$ The court expressly held that the right to travel is fundamental, but ultimately deemed Maine's restrictions likely to withstand strict scrutiny. The court found that there was no less restrictive means available to achieve the state's purpose given that, at the time, there was limited access diagnostic testing capacity. ${ }^{211}$ Notably, the state did not examine what the state's purpose in specific terms, beyond noting that "the pandemic is a compelling justification for restrictions on constitutional liberties." 212

Only a few plaintiffs have "challenge[d] the constitutionality of the very concept of a stay-at-home order, which some have described as "plac[ing] plaintiffs under house arrest unless they are engaged in activity the government deems essential or which are otherwise authorized." 213 Most courts have rejected these claims when they've addressed the plaintiffs' likelihood of success on the merits. ${ }^{214}$ In McGhee v. City of Flagstaff, for example, a federal district court

208. In some cases, courts have relied on the Jacobson suspension doctrine to avoid determining whether a fundamental right is implicated by the challenged restriction. See, e.g., Amato v. Elicker, No. 3:20-cv-464, 2020 WL 2542788 (D. Conn. May 19, 2020) ("The Plaintiffs argue that [an executive order closing all non-essential businesses] violates their constitutional 'right to earn an honest living." ' I need not decide whether the Constitution protects such a right because, even if it did, states have broad powers to protect public health during epidemics ... . [T] he Governor's order has a "real or substantial relation" to public health and safety and the action is not "beyond all question, a plain, palpable invasion of rights.").

209. Roberts v. Neace, 457 F. Supp. 3d 595 (E.D. Ky. 2020).

210. Bayley’s Campground Inc. v. Mills, 463 F.Supp. 3d 22 (D. Me. 2020).

211. Id.

212. Id. at 30 .

213. Hawse v. Page, Case No. 4:20cv588, 2020 WL 2322999 (E.D. Mo. May 11, 2020) (internal quotation marks omitted) (denying defendants' motion to dismiss the plaintiff's substantive due process challenge to stay-at-home order without addressing the plaintiffs' likelihood of success on the merits because the defendants' motion did not address the plaintiffs' due process claim).

214. In some cases, courts did not reach the merits of these claims because they found it insufficiently likely that the stay-at-home order would be enforced. See, e.g., Faust v. Inslee, No. C20-5356, 2020 WL 2557329, *2 (W.D. Wash. May 20, 2020) (denying motion for a temporary restraining order to a plaintiff who had previously protested the stay-at-home order and planned to do so again on the grounds that she had "fail[ed] to establish a realistic threat of any criminal enforcement action as a result of her course of conduct"); Lighthouse Fellowship Church v. Northam, 
rejected the plaintiff's argument that orders to stay at home violated his rights to freedom of movement and travel. Applying the Jacobson suspension standard, the court noted that the order included exceptions for "engaging in constitutionally protected activities, outdoor exercise, caring for family members or friends in other residences, attending work or volunteering in essential functions, visiting retailers, and other "essential activities." ${ }^{215}$ Similarly, In Lawrence v. Colorado, a federal district court cautioned that state officials "underestimate the potential constitutional implications of a stay-at-home order" but ultimately upheld the challenged restrictions based on the Jacobson suspension doctrine. The court found that the plaintiff "has not shown that being denied [social visits or travel] under the present circumstances constitutes a plain and palpable deprivation of any recognized constitutional right." ${ }^{216}$ In Best Supplement Guide, LLC v. Newsom, a federal district court rejected the plaintiff's right to travel argument because "although the Supreme Court ... "certainly [is] not dismissive of the possibility"" that a right to intrastate travel exists, the court "cannot find that the State and County orders violate 'beyond all question' [quoting Jacobson] a right that is not yet known to exist." 217

Henry v. DeSantis may be the only case in which a federal district judge has authored an opinion expressly dismissing a Fourteenth Amendment challenge to a stay-at-home order without resorting to the Jacobson suspension doctrine. ${ }^{218}$ In addition to rejecting a First Amendment freedom-of-assembly challenge, the court found that the order to stay at home except for purposes the governor deemed essential did not infringe upon a fundamental right and thus did not trigger heightened scrutiny. Although the plaintiff's complaint centered primarily on the termination of her employment, which she attributed to the governor's restrictions, the court noted that " $[\mathrm{t}] \mathrm{ime}$ and again, the Supreme Court has determined that there

462 F. Supp. 3d 635, 644 (E.D. Va. 2020) (denying motion for injunction pending appeal under the Ex parte Young doctrine "because there is no evidence that the Governor himself enforced, threatened to enforce, or advised other agencies to enforce his Orders against Plaintiff or any other individual or entity") (internal quotation marks and citations omitted). Indeed, many governors and local officials explicitly assured the public that enforcement actions would be minimal or nonexistent. The use of purportedly mandatory public health orders as a form of strong recommendation in response to the coronavirus pandemic merits further attention from scholars of public health law and ethics.

215. McGhee v. City of Flagstaff, No. CV-20-08081-PCT-GMS, 2020 WL 2308479, *5 (D. Ariz. May 8, 2020).

216. Lawrence v. Colorado, 455 F. Supp. 3d 1036, 1076 (April 19, 2020) (citing City of Dallas v. Stanglin, 490 U.S. 19, 25, (1989)) (no general constitutional right of social association); Zemel v. Rusk, 381 U.S. 1, 15-16 (1965) (right to travel may be restricted where necessary to protect area from disease)).

217. Best Supplement Guide, LLC v. Newsom, No. 2:20-cv-00965-JAM-CKD, 2020 WL $2615022 * 5$ (E.D. Cal. May 22, 2020).

218. Henry v. DeSantis, 461 F. Supp. 3d 1244, 1254-55 (S.D. Fla. 2020). 
is no fundamental right to a job, or right to work."219

In County of Butler v. Wolf, the federal district court for the Western District of Pennsylvania departed from these precedents. ${ }^{220}$ Judge William Stickman held that Pennsylvania's stay-at-home order and closure of businesses violated the plaintiff's substantive due process rights to intrastate travel and to economic liberty. Relying on precedents invalidating laws prohibiting cruising, loitering, and vagrancy, as well as juvenile curfew laws, Judge Stickman identified rights to intrastate travel and freedom of movement as fundamental to the concept of ordered liberty. ${ }^{221}$ Although those precedents had applied intermediate scrutiny on the grounds that anti-loitering laws and similar restrictions on movement are akin to time, place, and manner restrictions on the freedom of speech, Judge Stickman argued that the greater intrusiveness of the stay-at-home order merited the application of strict scrutiny.

Noting that the economic liberty argument in Lochner had never been "repudiated" by the U.S. Supreme Court, Judge Strickland - erroneously according to the intervening century of precedents - also applied strict scrutiny to the order closing businesses not deemed life-sustaining. ${ }^{222}$ Economic rights to use one's property and earn one's livelihood as one sees fit have been overwhelmingly rejected as a basis for applying strict scrutiny under the U.S. Constitution in the modern era. ${ }^{223}$ As a matter of state constitutional law, however, some state courts have found them to be fundamental. For example, an Ohio trial court held that coronavirus emergency orders restricting business operations violated fundamental rights to "own and use property and earn a living" recognized in the state constitution. ${ }^{224}$

219. Id. at 1255 (citing Stop the Beach Renourishment, Inc. v. Fla. Dep't of Envtl. Protection, 560 U.S. 702, 722, (2010) (“[T]he 'liberties' protected by substantive due process do not include economic liberties.”); Helm v. Liem, 523 F. App’x 643, 645 (11th Cir. 2013) (“[T] he right to work in a specific profession is not a fundamental right.")).

220. County of Butler v. Wolf, No. 2:20-cv-677, 2020 WL 5510690 (W.D. Pa. Sept. 14, 2020), stay pending appeal granted, No. 20-2936, 2020 WL 5868393 (3d. Cir. Oct. 1, 2020).

221. Id. (citing Lutz v. City of York, 899 F.2d 255 (3d Cir. 1990)); City of Chicago v. Morale, 527 U.S. 41, 53-54 (1999); Papachristou v. Jacksonville, 405 U.S. 156, 164-65 (1972); Waters v. Barry, 711 F. Supp. 1125, 1134 (D.D.C. 1989).

222. $I d$.

223. See, e.g., SH3 Health Consulting, LLC v. Page, 459 F.Supp. 3d 1212, 1226 (E.D. Mo., May 8, 2020) (rejecting the notion that the Due Process Clause of the Fourteenth Amendment protects plaintiffs' "right to conduct their business and to earn a living"); Henry v. DeSantis 461 F.Supp. 3d 1244, 1255 (S.D. Fla. 2020) ("Time and again, the Supreme Court has determined that there is no fundamental right to a job, or right to work."); see also N.D. State Bd. of Pharmacy v. Snyder's Drug Stores, Inc., 414 U.S. 156, 167 (1973) (“"W]e emphatically refuse to go back to the time when courts used the Due Process Clause to strike down state laws, regulatory of business and industrial conditions, because they may be unwise, improvident, or out of harmony with a particular school of thought.") (quoting Williamson v. Lee Optical of Okla., Inc., 348 U.S. 483, 488 (1955)).

224. Rock House Fitness, Inc. v. Acton, No. 20CV000631, 2020 WL 3105522 at *4 (May 20, 
Although Judge Strickland's order is an outlier unlikely to be followed by many other judges, the lack of more precedents upholding stay-at-home orders following application of ordinary standards of review is concerning. Some feel strongly that stay-at-home orders should be re-imposed now that we are entering what are likely to be the darkest days of the current pandemic. I do not share this view based on what we now understand about the risks of transmission. But the lack of supportive precedents should also be concerning to legislators as they prepare for the next pandemic, which could present even greater dangers. The fact that most judicial opinions upholding stay-at-home orders have relied heavily on the Jacobson suspension doctrine is not surprising, given the widespread support for the doctrine among lower courts in the early months of 2020 when stay-athome orders were common. It is concerning, however, that orders to stay at home are now more vulnerable to constitutional challenge - during this pandemic and the next one-with only one clearly valid precedent supporting their use. ${ }^{225}$

Overall, however, most community mitigation measures have been upheld by at least some courts without relying exclusively on the suspension doctrine. Moreover, there have been very few instances in which courts have applied strict scrutiny to these measures. While rights to freedom of personal movement and travel are the most intuitive fit for broad challenges to stay-at-home orders, they are not well established as fundamental rights triggering strict scrutiny under the Fourteenth Amendment. Setting aside religious freedom cases, most community mitigation restrictions have been upheld so long as they are not arbitrary, capricious, or unreasonable. ${ }^{226}$

\section{Arbitrary, Capricious, or Unreasonable Government Action}

State and local governments have broad authority to regulate or even close businesses in the name of protecting the public's health. However, the Fourteenth Amendment's guarantees of equal protection and due process have been interpreted as barring the exercise of that authority in an arbitrary, capricious, or otherwise unreasonable manner. This prohibition applies even in situations where the parties do not successfully assert a fundamental right or suspect

2020).

225. Henry v. DeSantis, 461 F. Supp. 3d 1244, at 1254-55 (S.D. Fla. 2020).

226. See, e.g., League of Indep. Fitness Facilities and Trainers v. Whitmer, 814 Fed. App'x. 125, 126 (6th Cir. 2020) ("Some [legal challenges to COVID-19 orders] involve individual rights for which precedent requires courts to apply a heightened level of scrutiny to government actions, for example, the free exercise of religion. But many other cases involve executive actions that, by precedent, are viewed only through the lens of a very modest, or 'rational basis,' standard of review. And almost without exception, courts in those instances have appropriately deferred to the judgments of the executive in question.") (citations omitted). 
classification. ${ }^{227}$ The rational basis standard of review applied to these challenges is easily met and few courts applying it have struck down coronavirus emergency measures. ${ }^{228}$ Nonetheless, the decisions upholding orders reveal the extent to which state and local officials have struggled to craft emergency provisions that draw a multitude of distinctions determining which businesses are ordered to close or operate at reduced capacity or require face-masks or institute other controls and which gatherings are prohibited or subjected to specific caps or other requirements.

Early challenges called on courts to examine executive officials' designation of businesses as essential or not. In McCarthy v. Cuomo, for example, a federal district judge rejected an equal protection challenge from an owner of a business deemed non-essential. "Given the seriousness of the COVID-19 pandemic," the court found it "exceedingly unlikely that plaintiffs will be able to demonstrate that the [governor's orders] do not have a rational basis." ${ }^{229}$ Consistent with other opinions in the early months of the pandemic, she did not offer further analysis.

Matters became even more complicated as executive-branch officials lifted restrictions on some types of non-essential businesses while keeping others closed. In League of Independent Fitness Facilities and Trainers, Inc. v. Whitmer, a threejudge panel of the Sixth Circuit provided an extended discussion of what rational basis requires of state and local executives seeking to defend classifications between businesses whose operations are restricted and those allowed to conduct business as usual. The plaintiffs argued that the Michigan governor's order violated equal protection "by treating indoor fitness facilities (which remain completely closed) differently from bars, restaurants, and salons (which may open with restrictions)." 230 The lower court had issued a preliminary injunction prohibiting enforcement of the order against the plaintiffs, based on a finding that the differential treatment of these facilities "failed even [the] deferential test" applied to non-suspect classifications "because the Governor did not adequately explain during the hearing ... her somewhat unique treatment of indoor fitness

227. If a state action neither infringes a fundamental right nor draws a suspect nor quasi-suspect classification, courts apply rational basis review. FCC v. Beach Commc'ns, Inc., 508 U.S. 307, 313 (1993).

228. See, e.g., Hund v. Cuomo, Case No. 20-cv-1176, 2020 WL 6699524 (W.D.N.Y. Nov. 13, 2020) (granting a preliminary injunction barring enforcement of an order prohibiting advertised and ticketed music performances at restaurants while allowing music performances that are "incidental to the dining experience" on the grounds that it was likely to be found arbitrary and thus would fail even the Jacobson suspension standard of review).

229. McCarthy v. Cuomo, Case No. 20-cv-2124, 2020 WL 3286530, *6 (E.D.N.Y. 2020); see also Commcan, Inc., v. Baker, No. 2084CV00808-BLS2, 2020 WL 1903822 (Mass. Dist. Ct.April $16,2020)$ ("[T]he Governor was not legally required to implement a different alternative or ensure that his emergency closure orders impose the smallest possible economic burden on [the plaintiffs].").

230. League of Indep. Fitness Facilities and Trainers, 814 Fed. App'x. at 126 (granting stay of lower court injunction). 
facilities, relying instead on conclusory statements that gyms are "dangerous.",231 The court of appeals stayed the lower court's injunction, reasoning that, "unlike exacting forms of scrutiny applied in other contexts, the Governor was not required to explain that choice at all, let alone exhaustively. Rather, the relevant standard merely requires "rational speculation" that offers "conceivable" support to the Governor's order.",232

The Sixth Circuit panel went on to assess the governor's evidence in support of the closure of indoor fitness centers "[a]gainst the backdrop of that low bar," and quoted the governor's court filings at length. I include the lengthy passage here because it provides a helpful illustration of how distinctions such as these have been based on differential risk of increasing community transmission:

[E]ven the most ventilated indoor facility is susceptible to respiratory spread of the virus. The danger is only amplified when people congregate (even with social distancing) in a confined space and work out. By its nature, working out is sustained vigorous physical activity, which necessarily means heavy breathing and sweating and, therefore, acute, propulsive bursts of virus shedding by anyone in that confined space who might be infected. Apart from individual exercisers in proximity, there is the added risk of individuals working out together or organized groups working out for extended trainer-led sessions. And the risk of viral spread is only heightened further by the sharing of exercise equipment among many different people over the course of the day, even when good-faith efforts are made to clean that equipment after each use. At a fitness center, these factors merge to significantly increase the incidence of this highly contagious and asymptomatically transmittable virus spreading. ${ }^{233}$

The appellate court held up the governor's district court brief as "a paradigmatic example of "rational speculation.",234 Under the circumstances, the court declined to require the governor to offer "evidence or empirical data" to support the distinctions drawn in her emergency order. ${ }^{235}$ Rather, the court "must accept [the Governor's] generalizations even when there is an imperfect fit between means and ends." 236 The appellate court expressed understanding for the district court's "frustration at the justifications underlying these executive actions,"

231. Id. (internal citations omitted).

232. Id.

233. Id. at *3 (quoting Governor's Dist. Ct. Br. at 20).

234. $I d$.

235. Id. (quoting FCC v. Beach Commc'ns, Inc., 508 U.S. 307, 315 (1993)).

236. Id. (quoting Heller v. Doe, 509 U.S. 312, 321 (1993)). 
noting that "[a]mong other uncertainties of the decisionmaking process, the Order does not close every venue in which the virus might easily spread." ${ }^{237}$ But, the court reasoned, to avoid being arbitrary or capricious "the Governor's order need not be the most effective or least restrictive measure possible to attempt to stem the spread of COVID-19." "238 The court concluded with a genuflection to the politically accountable branches: "Crises like COVID-19 can call for quick, decisive measures to save lives. Yet those measures can have extreme costs costs that often are not borne evenly. The decision to impose those costs rests with the political branches of government ...."239

In Talleywhacker, Inc. v. Cooper, the Eastern District of North Carolina offered similar analysis to uphold restrictions that "require[d] entertainment and fitness facilities to remain closed, but allow[ed] restaurants, breweries, wineries, and distilleries to reopen, along with personal care, grooming, and tattoo businesses." 240 The court deferred to the governor's reliance on the advice of state health secretary, Dr. Mandy Cohen:

Defendant drew this classification upon the advice of Dr. Cohen, and her team of medical advisors, who concluded that entertainment and fitness facilities "bring together large groups of people in an indoor setting where they will be largely stationary or sitting for long periods of time." As a result, "the risk of spreading COVID-19 is higher" at these facilities. Moreover, at such venues, "patrons' compliance with personal protection measures is likely to decrease" because "alcohol consumption [is] expected and part of the entertainment environment." Finally, where behavior at such venues often includes yelling over loud music, singing, and dancing, and where COVID-19 is transmitted through respiratory droplets, these venues exacerbate the risk of COVID-19 transmission. ${ }^{241}$

Based on what it deemed "plausible reasons," the court concluded "the classification drawn by [the governor's executive order] is rationally related to the state's legitimate interest." ${ }^{242}$ The court found the plaintiffs' assertions that their adult entertainment venues presented risks similar to restaurants, which were allowed to reopen, noting the "importance" of restaurants "to the community as a whole."243 The court expressed approval of Dr. Cohen's description of the governor's orders as "employ[ing] a 'dimmer switch' approach to the reopening of businesses, gradually easing restrictions on high-risk activities, instead of allowing all businesses to reopen at once, in order to monitor the spread of COVID-

237. Id.

238. Id.

239. Id. at *4.

240. Talleywhacker, Inc. v. Cooper, 465 F. Supp. 3d 523 (E.D.N.C. 2020).

241. Id.

242. $I d$.

243. Id. 
19." 244

Predictably, most community mitigation measures have survived highly deferential rational basis review. Nonetheless, courts have probed the classifications state and local executives have drawn between different types of businesses and gatherings. Their analysis illustrates the need for state and local executives to carefully articulate the scientific understanding on which their determinations are based.

\section{Lack of Statutory Authority for Executive Action}

In March 2020, when state and local executive-branch officials surveyed the authorities available to them by statute, many found that powers to ban gatherings, order businesses to close, ban gatherings, and order the general public to shelter in place - as officials in China and Italy had done - were not clearly defined. One of the most important effects of state and local emergency declarations is that they trigger ex ante delegations of authority from the legislature. By passing an emergency powers statute, the legislature pre-commits to a delegation of some or in the case of California, all - of the state's power to regulate for the general welfare to executive-branch officials so they may respond swiftly in a crisis. But few states have specific statutory provisions authorizing officials to mandate social distancing and use of face masks. Several courts have fielded claims that coronavirus emergency orders were ultra vires because they exceeded the scope of executive-branch officials' statutory authority.

For example, as the plaintiffs in one of the earliest coronavirus challenges pointed out, Pennsylvania public health emergency statutes did not equip the governor with any specific "power or authority to shutter businesses." ${ }^{245}$ But Governor Tom Wolf relied on a curfew provision in an older disaster management statute, which empowered him to control "movement of persons" and "occupancy of premises" within a declared disaster area. ${ }^{246}$ On March 22, in a per curiam decision in Civil Rights Defense Firm, P.C., v. Wolf, the Pennsylvania Supreme Court denied the plaintiffs' request for injunctive relief without discussing the merits. ${ }^{247}$ A few weeks later in Friends of Danny DeVito v. Wolf, (no, not that Danny DeVito ${ }^{248}$ ), the court described the governor's "broad authority" derived

244. Id.

245. Civil Rights Defense Firm v. Wolf, Civ. Docket No. 63 MM 2020, Petitioner's Emergency, Ex Parte Application for Extraordinary Relief at 14 (Mar. 20, 2020).

246. Pa. OfFice of the Governor, Order of the Governor of the COMMONWEAlth of Pennsylvania Regarding the Closure of All Businesses that are Not Life Sustaining (Mar. 19, 2020) (citing 35 PA. CONS. STAT. § 7301(f)), https://www.scribd.com/document /452416027/20200319-TWW-COVID-19-Business-Closure-Order.

247. Civil Rights Defense Firm v. Wolf, Civ. No. 63 MM 2020 (Pa. 2020).

248. Friends of Danny DeVito v. Wolf, 227 A.3d 872, 881 (Pa. 2020). ("Petitioner Friends of 
from the state constitution and the disaster management statute and "firmly grounded in the commonwealth's police power." 249 After a lengthy discussion of the statutory interpretation cannon of ejusdem generis, which counsels against "the expansion of a list of specific items to include other items not 'of the same kind' as those expressly listed," 250 the court determined "[t]he COVID-19 pandemic is, by all definitions, a natural disaster and a catastrophe of massive proportions." ${ }^{" 251}$ Thus, it fell within the disaster management statute's provision for any "other catastrophe which results in substantial damage to property, hardship, suffering or possible loss of life."252 Any other determination could have resulted in invalidation of Pennsylvania's social distancing orders. The state's subsequent face mask order, in contrast to the stay-at-home orders challenged in Friends of Danny DeVito, was issued by the state secretary of health pursuant to the health department's authority "to determine and employ the most efficient and practical means for the prevention and suppression of disease" $" 253$ and other public health powers. ${ }^{254}$ It's unclear why Governor Wolf declined to rely on the health department's authority to issue the state's stay-at-home order, though it is possible doing so would have opened up the order to an administrative law challenge for failure to follow the appropriate rulemaking process.

Other courts have been less generous in their statutory interpretation of executive emergency powers. In Rock House Fitness v. Acton, ${ }^{255}$ an Ohio trial court ruled that Ohio Department of Health Director Amy Acton's April 30 order maintaining limits on high-risk settings like fitness centers while lifting other restrictions was ultra vires. The court largely ignored Acton's assertion that the order was authorized by a general grant of authority to "make special orders . . . for preventing the spread of contagious or infectious diseases." 256 The judge instead characterized Acton's order as having "quarantined the entire people of the state of Ohio, for much more than 14 days" in violation of the statutory guardrails

Danny DeVito ... is a Pennsylvania candidate committee ... formed to operate and administer the candidacy of Danny DeVito, a candidate for the 45th District of the Pennsylvania State House of Representatives.").

249. Id. at $885-86$.

250. Id. at 888 .

251. Id. at 889 .

252. Id.

253. 71 PA. CONS. STAT. § 532(a).

254. The health secretary's mask orders also refer to several other provisions, but they appear to be less on point than 71 PA. Stat. § 532(a). Pa. DeP'T of Health, Order of The Secretary of the Pennsylvania Department of Health Requiring Universal Face Coverings (July 1, 2020), https://www.governor.pa.gov/wp-content/uploads/2020/07/20200701-SOH-Universal-FaceCoverings-Order.pdf.

255. Rock House Fitness, Inc., v. Acton, No. 20CV000631, 2020 WL 3105522 (Ohio Ct. Com. Pl. May 20, 2020).

256. Ohio Dep't of Health, Director's Stay Safe Ohio Order (Apr. 30, 2020), . 
applicable to individual quarantine orders. ${ }^{257} \mathrm{He}$ went on to hold that " $[\mathrm{t}]$ he director has no statutory authority to close all businesses, including the plaintiffs' gyms, which she deems non-essential[,] for a period of two months. She has acted in an impermissibly arbitrary, unreasonable, and oppressive manner and without any procedural safeguards." 258

In Wisconsin Legislature v. Palm - arguably the most notorious court decision in the pandemic to date ${ }^{259}$ — the Wisconsin Supreme Court lifted the state health department's extended stay-at-home order ${ }^{260}$ pursuant to a request for preliminary injunction from the state legislature. ${ }^{261}$ The court described SecretaryDesignee Andrea Palm ${ }^{262}$ as having "quarantine[d] '[a]ll individuals present within the State of Wisconsin' by ordering them 'to stay at home or at their place of residence' with exceptions she deems appropriate." ${ }^{263}$ The court found that Palm's order exceeded the scope of the state quarantine statute because it was "not based on persons infected or suspected of being infected." 264

Moreover, the court found the order was not a permissible exercise of the health department's broad authorities to "implement all emergency measures necessary to control communicable diseases" or "to [guard] against any introduction of communicable disease into the state" under other provisions of the state's public health statute. ${ }^{265}$ In the words of Justice Patience Roggensack's

257. Rock House Fitness, 2020 WL 3105522 , at *4.

258. Id.

259. The Wisconsin Supreme Court's other big coronavirus decision-blocking the governor's order suspending in-person voting in the state's April 7 primary election-would be a close runner up. Wis. Legislature v. Evers, Civ. No. 2020AP608-OA, unpublished order (Wis. April 6, 2020); see also Republican National Committee v. Democratic National Committee, 140 S. Ct. 1205 (2020) (staying district court order granting a preliminary injunction which would have required the state to count absentee ballots postmarked after election day).

260. The order invalidated by Wisconsin Legislature v. Palm was Wisconsin Dep't of Health Svcs. Emergency Order 28 (Apr. 16, 2020). The April 16 order extended restrictions which had previously been imposed by the secretary in a March 24 health department order.

261. Wis. Legislature v. Palm, 942 N.W.2d 900 (Wis. 2020).

262. The state senate has refused to hold a vote on Palm's confirmation since her nomination in 2019. Anthony Dabruzzi, Wisconsin Health Secretary Still Awaits Confirmation from Senate, SPECTRUM News 1 (Apr. 28, 2020), https://spectrumnews1.com/wi/madison/news /2020/04/28/health-secretary-still-not-confirmed-.

263. Wis. Legislature, 942 N.W.2d at 916 (Wis. 2020); see also Rock House Fitness, Inc., v. Acton, 2020 WL 3105522 (Ohio Ct. Com. Pl. May 20, 2020) (applying statutory guardrails for quarantine and isolation of individuals to Ohio's order closing businesses, restricting travel, and ordering the general public to stay at home); see also Lindsay F. Wiley, Wisconsin's "Safer at Home" Order Isn't a Quarantine-But that Doesn't Mean it Isn't Necessary to Control the Spread of Coronavirus, AM. CONST. SOC'Y EXPERT F. (May 7, 2020), https://www.acslaw.org/expertforum/wisconsins-safer-at-home-order-isnt-a-quarantine-but-thatdoesnt-mean-it-isnt-necessary-to-control-the-spread-of-coronavirus/.

264. Wis. Legislature v. Palm, 942 N.W.2d 900 (Wis. 2020).

265. Id. at 914-18. 
opinion for the majority, the court "cannot expansively read statutes with imprecise terminology that purport to delegate lawmaking authority to an administrative agency."266 This result, according to Roggensack, was dictated by a 2011 amendment to the state's Administrative Procedure Act (APA), part of thengovernor Scott Walker's efforts to roll back business regulation. ${ }^{267}$ The court held that agencies were prohibited from "circumventing [the 2011 amendment's] new 'explicit authority' requirement by simply utilizing broad statutes describing the agency's general duties or legislative purpose as a blank check for regulatory authority." 268 The court's narrow interpretation of broad grants of authority to control communicable disease was entwined with its expansive interpretation of a separate provision directing that "unless a rule has been promulgated [via an emergency rulemaking process subject to legislative veto] or the [agency] action is 'explicitly required or explicitly permitted by statute,' [the agency] has no power to implement or enforce its directives." 269

Public health advocates condemned the Wisconsin Supreme Court's decision as "reckless." 270 Champions of pro-business regulatory reform welcomed it as a sign that the court was "reining in" the administrative state. ${ }^{271}$ Because the broad power to control communicable disease did not "explicitly permit" compulsory social distancing via limits on business operations, gatherings, and travel, Wisconsin's extended "safer at home" order was lifted.

\section{E. Separation of Powers Constraints on Executive Action}

The nondelegation doctrine - the principle that broad delegations of policymaking authority from the legislature to the executive may violate constitutionally mandated separation of powers - is a more prominent limit on

266. Id. at 917.

267. Id. The court relied on WIS. STAT. $§ 227.10(2 \mathrm{~m})$ (2011), which provides: "No agency may implement or enforce any standard, requirement, or threshold, including as a term or condition of any license issued by the agency, unless that standard, requirement, or threshold is explicitly required or explicitly permitted by statute or by a rule that has been promulgated in accordance with [proscribed rulemaking processes]." See MacIver Institute, Reining in the Administrative State: Wisconsin Legislature v. Palm and the Explicit Authority Requirement (May 27, 2020), https://www.maciverinstitute.com/2020/05/reining-in-the-administrative-state-wisconsin-

legislature-v-palm-and-the-explicit-authority-requirement/; Kirsten Koschnick (Comment), Making "Explicit Authority" Explicit Deciphering Wis. Act 21's Prescriptions for Agency Rulemaking Authority, 2019 WIS. L. REV. 993.

268. Wis. Legislature v. Palm, 942 N.W.2d at 917 (quoting Koschnick, supra note 267, at 996).

269. Id.

270. Representative Lisa Subeck Condemns Supreme Court rule in Wisconsin Legislature v. Palm, Wisconsin LEGISLATURE (May 14, 2020), https://legis.wisconsin.gov/assembly/78/subeck/news/press-releases/representative-lisa-subeckcondemns-supreme-court-rule-in-wisconsin-legislature-v-palm/.

271. See, e.g., MacIver Institute, supra note 267. 
administrative discretion in some states than it has been at the federal level. More routine public health regulations have been struck down in recent decades on separation of powers grounds in states with rigid limits on agency discretion. ${ }^{272}$ Courts rigorously reviewing broad delegations typically look for adequate statutory guardrails to guide implementation and judicial review to determine whether the legislature's authorization of decisionmaking power crosses the line from executive implementation into improper policy-making by executive-branch officials. ${ }^{273}$ This doctrine has reared its head in several state-court decisions reviewing coronavirus emergency measures.

In Wisconsin Legislature v. Palm, the state supreme court did not strike down the health secretary's order on nondelegation grounds, but invoked the nondelegation doctrine indirectly to call her actions into question. The court noted that "[a] delegation of legislative power to a subordinate agency will be upheld if the purpose of the delegating statute is ascertainable and there are procedural safeguards to insure that the board or agency acts within that legislative purpose."274 The court reasoned that procedural safeguards provided by rulemaking - which Secretary Palm had not followed - secured structural, as well as individual-rights constraints on administrative action: "Palm cannot point to any procedural safeguards on the power she claims. At oral argument, she continuously referenced judicial review; but judicial review takes place after an allegation is made that an individual's rights have been violated...."275 In addition to providing an opportunity for public comment, the rulemaking procedures at issue would also have permitted the legislature to functionally override Palm's orders without the support that would be required to adopt new legislation and survive a gubernatorial veto. Filing suit and asking the courts to intervene also allowed the legislature to shape the pandemic response without passing a new statute to constrain the administration's authority.

272. See, e.g., N.Y. Statewide Coal. of Hispanic Chambers of Commerce v. N.Y. City Dep't of Health \& Mental Hygiene, 16 N.E.3d 538, 541 (N.Y. 2014) (“[T]he New York City Board of Health, in adopting the "Sugary Drinks Portion Cap Rule", exceeded the scope of its regulatory authority. By choosing among competing policy goals, without any legislative delegation or guidance, the Board engaged in law-making and thus infringed upon the legislative jurisdiction of the City Council of New York."); Boreali v. Axelrod, 517 N.E.2d 1350 (N.Y. 1987) (holding that the New York State Public Health Council overstepped its regulatory authority when it adopted regulations prohibiting smoking in a wide variety of indoor areas open to the public that had previously been considered, but not adopted, by the state legislature).

273. See, e.g., Blue Cross \& Blue Shield of Mich. v. Milliken, 367 N.W.2d. 1, 51-53 (Mich. 1985) ("Challenges of unconstitutional delegation of legislative power are generally framed in terms of the adequacy of the standards fashioned by the Legislature to channel the agency's or individual's exercise of the delegated power.").

274. Wis. Legislature v. Palm, 942 N.W.2d 900 (Wis. 2020) (internal quotation marks and citations omitted).

275. Id. at 913 (internal citations omitted). 
Several months after the Wisconsin decision, the Michigan Supreme Court ruled that a 1945 civil defense statute - which the governor relied on to extend her emergency declarations after the legislature refused to renew them under a 1976 emergency management statute - was unconstitutional under the nondelegation doctrine. ${ }^{276}$ The majority of the court interpreted the language of the 1945 statute broadly. Typical for a mid-century civil defense statute, it empowered the governor to declare an emergency "[d]uring times of great public crisis, disaster, rioting, catastrophe, or similar public emergency within the state . . when public safety is imperiled." 277 Upon such a declaration, the governor was authorized to "promulgate reasonable orders, rules, and regulations as he or she considers necessary to protect life and property or to bring the emergency situation within the affected area under control." 278 The statute also included specific authority to control occupancy, ingress, and egress, and "places of amusement and assembly" within the area affected by the emergency. ${ }^{279}$ The court rejected the legislature's argument that the 1945 statute was inapplicable to epidemics. The majority also found a dissenting justice's argument that "public safety" emergencies are distinct from and exclude "public health" emergencies ${ }^{200}$ unpersuasive. Instead, the court declared the 1945 statute's delegation of the entirety of the state's police powers to the governor during a properly declared emergency unconstitutional.

The Michigan Supreme Court's nondelegation analysis relied on a state precedent tying the specificity of the statutory guardrails required to survive a nondelegation challenge to the specificity of the power the statute authorizes. "Challenges of unconstitutional delegation of legislative power are generally framed in terms of the adequacy of the standards fashioned by the Legislature to channel the agency's or individual's exercise of the delegated power. The preciseness required of the standards will depend on the complexity of the subject." ${ }^{281}$ Ultimately, "the standards prescribed for guidance must be as

276. In re Certified Questions, No. 161492, 2020 WL 5877599 (Mich. Oct. 2, 2020).

277. Мich. COMP. LAws.§ 10.31(1).

278. Id.

279. Id.

280. In re Certified Questions, No. 161492, 2020 WL 5877599, at*29 (Mich. Oct. 2, 2020) (Viviano, J., concurring in part and dissenting in part).

281. Id. at 13 (quoting Blue Cross \& Blue Shield of Mich. v. Milliken, 367 N.W.2d 1 (Mich. 1985)). The Michigan Supreme Court also cited Whitman v. American Trucking Ass'ns, 531 U.S. 457,475 , (2001) ("[T] he degree of agency discretion that is acceptable varies according to the scope of the power ... conferred.") and Synar v. United States, 626 F. Supp. 1374, 1386 (D.D.C. 1986) ("[T]he ultimate judgment regarding the constitutionality of a delegation must be made not on the basis of the scope of the power alone, but on the basis of its scope plus the specificity of the standards governing its exercise. When the scope increases to immense proportions ... the standards must be correspondingly more precise."). 
reasonably precise as the subject-matter requires or permits." 282 "In other words, it is one thing if a statute confers a great degree of discretion, i.e., power, over a narrow subject; it is quite another if that power can be brought to bear on something as 'immense' as an entire economy." 283 The court also pointed to the challenged order's invocation of criminal sanctions, its impact on fundamental rights, and its lack of hard time-limits as reasons to require more specific statutory limits than the 1945 statute's procedures for emergency declaration and it's reasonableness and necessity standards provided.

In the aftermath of these state supreme court decisions, Wisconsin and Michigan officials issued new orders relying on more specific statutory authorizations to restrict public gatherings. ${ }^{284}$ Challenges to these October orders were filed shortly thereafter, relying on statutory interpretation and nondelegation arguments. ${ }^{285}$ The greater specificity of the statutory authorizations at issue may be a saving grace, but it may also open the door to narrow statutory constructions that exclude the Michigan order's requirement of face masks in commercial establishments ${ }^{286}$ or the Wisconsin order's application to "spontaneous gatherings" of people transiently passing through commercial establishments. ${ }^{287}$

Other state supreme courts have rejected similar nondelegation challenges to coronavirus emergency orders. In Elkhorn Baptist Church v. Brown, the Oregon Supreme Court reversed a trial court ruling that would have lifted the state's

282. Id. (quoting Osius v. St. Clair Shores, 75 N.W.2d 25 (Mich. 1956) (alteration marks omitted)).

283. Id. at 14. Here, the court cited a Lochner-era precedent, Schechter Poultry Corp. v. United States, 295 U.S. 495, 539 (1935).

284. The Wisconsin order dated October 5, 2020 relies on Wis. STAT. § 252.02(3) (2015) ("The department may close schools and forbid public gatherings in schools, churches, and other places to control outbreaks and epidemics.”). The Michigan order dated October 9, 2020 relies on MiCH. COMP. LAWS $\S 333.2253$ ("If the director determines that control of an epidemic is necessary to protect the public health, the director by emergency order may prohibit the gathering of people for any purpose and may establish procedures to be followed during the epidemic to insure continuation of essential public health services and enforcement of health laws. Emergency procedures shall not be limited to this code.")

285. As of this writing, the Wisconsin order has been enjoined by an intermediate state court pending appeal. The court did not discuss the rationale for its finding that the challengers were likely to succeed on the merits. Tavern League of Wis., Inc. v. Andrea Palm, No. 2020CV128 (Mich. Ct. App., Oct. 23, 2020).

286. Mich. Dep't of Health \& Human Servis., Emergency Order Under MCL 333.2253 GAthering Prohibition AND FACE COVERING Order (Oct. 9, 2020), https://www.michigan.gov/documents/coronavirus/MDHHS epidemic order Gatherings masks bars sports - FINAL signed 704740 7.pdf.

287. Wis. DeP't of Health Servs., Emergency Order 3 - Limiting Public Gatherings (Oct. 6, 2020), https://content.govdelivery.com/attachments/WIGOV/2020/10/06/file attachments 1564232/EmO03-LimitingPublicGatherings.pdf?fbclid=IwAR3iXfWxqaJ4Ncudkar VF7dT0KyPPhnSgchVYG7XPIJVwdMJCnKBUpY0Ck4. 
compulsory social distancing provisions. ${ }^{288}$ The court held that neither a 28-day statutory time limit on public health emergencies ${ }^{289}$ nor a 30 -day limit on a constitutional provision governing catastrophic disasters ${ }^{290}$ limited the governor's coronavirus response measures because they were independently authorized by a broader emergency management statute that does not include time limits. ${ }^{291}$ Moreover, the court found that delegation of all police powers to the governor without statutory time limits did not violate the state's nondelegation doctrine. The court found the governor's emergency powers are limited by statutory provisions requiring them "to be exercised in a manner consistent with ... address[ing] the declared emergency" and permitting the legislature to terminate the governor's emergency declaration. ${ }^{292}$ The court also noted the powers were subject to civil liberties constraints under the federal and state constitutions. ${ }^{293}$

In a similar case, Beshear v. Acree, the Supreme Court of Kentucky rejected a nondelegation challenge by the state's attorney general (an independently elected official who is a political rival of the governor) and business owners. ${ }^{294}$ The court reasoned that the state constitution "which provides for a part-time legislature incapable of convening itself, tilts toward emergency powers in the executive branch." ${ }^{295}$ The governor's orders have relied on a 1998 emergency management statute authorizing him to declare curfews and establish their limits, prohibit or limit the sale or consumption of goods, and "to perform and exercise other functions, powers, and duties deemed necessary to promote and secure the safety and protection of the civilian population." 296 The state supreme court held that "to the extent [the governor's emergency powers] are perceived as legislative, [the statute] is a lawful delegation of that power with sufficient standards and procedural safeguards to pass constitutional muster." "297 The court noted the potential danger of overruling decades of precedent "recogniz[ing] the lawful delegation of legislative powers ... especially in circumstances that would leave the Commonwealth without day-to-day leadership in the face of a pandemic affecting all parts of the state.,"298

Legislative efforts to constrain executive action played an important role in other states as well. Although the Pennsylvania Supreme Court blessed the

288. Elkhorn Baptist Church v. Brown, 366 Or. 506 (2020).

289. OR. REV. STAT. § 433.

290. OR. CONST. art. X-A.

291. Id. (citing OR. REV. STAT. § 410).

292. Id.

293. Id.

294. Beshear v. Acree, No. 2020-SC-0313-OA, 2020 WL 6736090 (Ky. Nov. 12, 2020).

295. Id. at *1.

296. Ky. Rev. Stat. 39A.100.

297. Beshear, $2020 \mathrm{WL} 6736090$ at *1

298. Id. 
governor's exercise of sweeping powers to respond to the pandemic, it also noted in Friends of Danny DeVito that "[a]s a counterbalance to the exercise of the broad powers granted to the Governor, the Emergency Code provides that the General Assembly by concurrent resolution may terminate a state of disaster emergency at any time." ${ }^{299}$ Several weeks later, in Wolf $v$. Scarnati, the Pennsylvania Supreme Court rejected the validity of the legislature's attempt to do exactly that ${ }^{300}$ In a case similar to Wolf v. Scarnati, Kansas Governor Laura Kelly brought suit seeking clarification as to whether the legislature's attempted revocation of her emergency order was valid. ${ }^{301}$ In Kelly v. Legislative Coordinating Council, the Kansas Supreme Court held that the legislative coordinating council lacked statutory authority to revoke the order following the procedure it adopted, rendering its purported revocation a legal nullity. ${ }^{302}$

\section{PROPOSED StATE LEGISLATIVE REFORMS}

Broadly defined statutory limits - such as those the Oregon and Kentucky supreme courts have deemed adequate - should be enough to save public health measures from running afoul of loose nondelegation constraints in most states. But clearer statutory guardrails would put compulsory social distancing and face mask orders on firmer footing. Statutory requirements are also crucial to ensure individual rights, public health necessities, and other public priorities are balanced in a way that is clear to voters seeking to hold state, local, and federal policymakers politically accountable.

Legislatures should revise state public health emergency statutes, local public health emergency ordinances, and the federal Public Health Service Act to give executive-branch officials the authority they need to respond to a crisis swiftly while setting forth ex ante statutory limits on executive discretion. These statutes already provide specific authorizations and statutory guardrails for individually targeted measures like compulsory screening, isolation, and quarantine. New legislation is needed to provide similarly specific authorizations and guardrails for compulsory measures to increase social distancing and use of personal protective equipment among the general public, regardless of known infection or exposure, during a declared public health emergency.

Statutory guardrails should provide a basis for courts to determine whether executive actions are ultra vires and to ensure that broadly defined powers do not run afoul of constitutional prohibitions on legislative delegations of policymaking authority. Nondelegation doctrine is not rigorous enough to impose significant

299. Friends of Danny DeVito v. Wolf, 227 A.3d 872, 881, 886 (Pa. 2020).

300. Wolf v. Scarnati, No. 104 MM 2020, 2020 WL 3567269 (Pa. July 1, 2020).

301. Kelly v. Legislative Coordinating Council, 460 P.3d 832 (Kan. 2020).

302. Id. 
limits on emergency-powers delegations under most state-court precedents, ${ }^{303}$ but the coronavirus cases reveal vulnerabilities that should be addressed through legislative reforms nonetheless.

Although I call for specific statutory authorizations based on the lessons learned in this pandemic, I am cognizant that statutory guardrails should be drafted broadly enough to address serious public health threats that may differ in important ways from SARS-CoV-2. My primary focus is on serious communicable diseases with epidemic potential - those caused by the appearance of a novel or previously controlled or eradicated infectious agent or toxin ${ }^{304}$ that is transmissible from person to person and poses a high probability of spreading rapidly to many people and causing a large number of deaths or serious disabilities in the affected population. ${ }^{305}$ An intentional attack or accidental release of a biologic, radionuclear, or chemical agent that is not transmitted from person to person may warrant similar actions, including orders to shelter in place or use personal protective equipment, but I do not address those scenarios in detail here.

The next public health emergency will almost certainly raise new issues whether because it's driven by different routes of transmission or exposures, has a higher case fatality rate, or disproportionately affects different age and demographic groups, such as children or young adults. To address the coming stages of this pandemic and other public health emergencies we may face in the future, legislatures should equip executive officials with a range of alternatives that can be tailored to the crisis at hand.

Here, my aim is to begin a conversation by setting forth general principles as well as some specific examples of how they might be implemented in draft legislation. I am certain my proposals will generate opposing views. Civil libertarians may see them as insufficient to protect individual rights. Public health advocates may view them as hobbling a swift and nimble emergency response. The debates will inevitably be heated. It's time for them to begin.

303. See, e.g., Blue Cross \& Blue Shield v. Milliken, 367 N.W.2d 1, 52-53 (Mich. 1985).

304. "Infectious diseases are caused by agents (also known as pathogens) or by the toxins they produce. Most infectious disease pathogens are viruses, bacteria, or fungi. Parasitic diseases are caused by protozoa or helminths (worms). With the exception of prions (misfolded proteins that cause some types of encephalopathies), all known infectious disease pathogens are [biological] organisms." Gostin \& WiLEY, supra note 3, at 347 (emphasis added).

305. A communicable disease is an infectious disease that is transmissible from person to person, including through indirect routes of transmission. A serious communicable disease is one that is virulent enough to cause death or serious disabilities in people who are infected. A serious communicable disease with epidemic potential is one with potential to spread rapidly to many people. The term pandemic is used to describe the global experience of coronavirus epidemics across a wide region of the globe. See id. 
A. The Strategic Purpose of Orders, the Scientific Understanding on which They are Based, and Criteria for Lifting Them Should be Disclosed to the Public in Specific Terms

Transparency, accountability, and sustainability are essential to maintaining the public's trust, which is a precious resource in a public health emergency. ${ }^{306}$ Constitutional challenges have, to some extent, required state and local executives to articulate to the courts (and, indirectly, to the public) the purpose of their orders and the scientific understanding on which they are based. But for the most part, executives have stated their purposes in terms that are far too general to ensure accountability.

In particular, most state and local officials have not been transparent about the extent to which the success and sustainability of state and local orders depends on federal intervention. In the US, state and local executives hold the reins on social distancing and face mask orders. But they lack the financial resources and interstate coordinating authority required to ramp up testing, contact tracing and financial supports for households and businesses. ${ }^{307}$ As a result, state and local leaders were not equipped to make good use of the time bought by strict stay-athome orders in the spring. And on their own, they could not achieve suppression. In the fall, when mitigation efforts were most needed in many places, some officials imposed harsh limits on private gatherings that do not generate revenue while allowing high-risk commercial establishments to stay open. They could have been more transparent about the fact that the lack of federal financial support for businesses and workers made business closures untenable so they were doing the best they could under the circumstances. ${ }^{308}$ Instead, many claimed that evidence (which they did not release to the public), indicated private gatherings, rather than workplaces or commercial establishments, were the greatest factor driving increased community transmission. ${ }^{309}$ Statutory requirements could ensure greater transparency and accountability by clarifying what state and local executivebranch officials can - and cannot - achieve on their own without federal assistance.

An individualized risk assessment requirement would effectively take compulsory social distancing and face covering orders off the table in a situation

306. Gostin, Burris \& Lazzarini, supra note 15, at 94-95.

307. See Lindsay F. Wiley, Federalism in Pandemic Prevention and Response, in COVID-19 Rapid Legal Assessment (Scott Burris, Wendy Parmet, \& Lance Gable, eds.) (2020).

308. Amanda Mull, The Logic of Pandemic Restrictions is Falling Apart, THE AtLantic (Nov. 25, 2020), https://www.theatlantic.com/health/archive/2020/11/pandemic-restrictions-nologic/617204/.

309. Apoorva Mandavilli, Small Gatherings Spread the Virus, but Are They Causing the Surge?, N.Y. Times (Nov. 23, 2020), https://www.nytimes.com/2020/11/23/health/coronavirus-holidaygatherings.html. 
where community transmission is widespread and access to rapid, reliable testing is limited. The MSEHPA and many state statutes subject individually targeted measures - such as compulsory testing, isolation, quarantine, treatment, and vaccination - to procedural requirements aimed at ensuring an impartial and individualized assessment of the risks the individual poses of transmitting infection to others. Imposing such a requirement on compulsory social distancing and face covering would mean that each individual and business would be entitled to a notice, a hearing, and representation by counsel before restrictions could be deemed justified by the risk the individual or businesses poses to others. In theory, the courts could have determined that an individualized risk assessment is constitutionally required to justify business closures, orders limiting travel, and orders mandating the use of face coverings. Doing so would have effectively required the government to make testing more widely available so that individually targeted measures could be used in place of the more disruptive forms of social distancing. But this approach was stymied by our federal system of government. State and local governments hold the reins on social distancing and face masks. But only the federal government has adequate resources (states are prohibited from deficit-spending) and interstate and international authority to coordinate supply chains to ensure access to testing. Once transmission becomes widespread, state and local leaders simply are not equipped to implement a response that relies solely on individually targeted measures following individualized risk assessments.

Instead of guaranteeing rights to procedural protections aimed at ensuring an individualized assessment, statutory guardrails should require executive branch officials to articulate their generalized risk assessment to the public at large. Statutes should require officials to state: (1) the strategic purpose orders are intended to serve, (2) the scientific understanding on which they are based, and (3) the criteria that will be relied on to determine whether they are working and when they can be modified or lifted. Orders should be time limited - but subject to an unlimited number of renewals - to ensure officials communicate the scientific understanding behind any assumptions that have led them to extend or modify restrictions.

Even in the absence of a statutory disclosure mandate, state and local officials could adopt this transparency principle of their own accord. Disclosure requirements will allow reviewing courts to determine whether the timing and degree of restrictions and mandates are based on the best available scientific understanding regarding the risk of transmission and whether the means adopted are consistent with a strategic purpose. Thus, disclosures may decrease the risk of orders being overturned on constitutional grounds. Perhaps more importantly, disclosure requirements will facilitate political accountability by clarifying the choices and responsibility of elected officials at each level of government. Indeed, that may be one reason why a statutory mandate is necessary to prompt officials to 
provide the level of transparency that pre-pandemic guidance recommended.

Coronavirus opinions have generally assumed that the purpose of executive orders is obvious and unchallenged: to combat the pandemic. But such a broadly defined purpose does little to ensure transparency and accountability. A more specific statement of the strategic purpose for executive orders should identify the criteria by which success or failure will be evaluated. If the strategic purpose of the orders is mitigation to keep the curve of a communicable disease epidemic within available health care capacity, then the relevant criteria may relate to actual or projected availability of hospital resources. If the strategic purpose is mitigation to buy time for implementation of other responses, such as testing and tracing or a vaccine or therapeutic, then the relevant criteria may relate to the attainment of specific milestones in implementation. If the strategic purpose is suppression, the relevant criteria may be expressed solely in terms of attaining a specific benchmark in measures of transmissibility.

Whether the stated criteria are attainable or not and whether they strike the right balance between disease control and other priorities must be left to constituents to judge. ${ }^{310}$ If, for example, a state or local government order specifies that it will remain in effect until the percent-positive rate of screening tests falls below a certain threshold (indicating sufficient testing capacity) or until the percentage of newly reported cases that were known contacts of previously reported cases rises above a certain threshold (indicating a transition from widespread community transmission to more localized transmission compatible with suppression), then it will be clearer to constituents that they should pressure federal and other officials to provide the resources necessary to achieve those benchmarks. If the order specifies a suppression goal and the constituents feel that is not feasible or not justified given the burdens that would be required, they may pressure the legislature to modify or lift the executive order. If the order specifies a goal of mitigation to stay within available health care capacity and constituents feel that is not ambitious enough, they may pressure the executive to take a more aggressive approach. "Crush the curve" proponents did exactly that in mid-April, and successfully convinced some governors to leave restrictions in place a little longer.

Executive officials should also be required to articulate the current scientific understanding on which their orders - including any extensions or modifications of previous orders - are based. ${ }^{311}$ For communicable disease, the risk of transmission should be assessed in terms of the virulence and transmissibility of the infectious agent or toxin, the routes of transmission, and the level of community

310. See Honig, supra note 4.

311. Cf. Gostin, Burris \& Lazzarini, supra note 15, at 121 (arguing that compulsory measures should be based on a demonstrated threat of significant risk). 
transmission in the affected area. Virulence refers to an agent's capacity to cause overt disease and death in a person who is infected. It is typically measured in terms of infection-fatality or case-fatality rates - the proportion of infected individuals (or those with confirmed infections, known as "cases") who die of the disease - though these measures do not account for serious and potentially longterm morbidity among survivors. ${ }^{312}$ Transmissibility refers to an agent's capacity to spread from person to person. ${ }^{313}$ It is typically measured in terms of the reproduction number (also known as R0 or "R naught"). As we have seen with SARS-CoV-2, virulence and transmissibility are not static measures inherent to a particular agent or toxin, rather they are influenced by characteristics of the affected population and the environmental, social, economic, political, and cultural factors that shape how people interact with each other and the course of infection. Executive officials must be alert to the dynamic nature of virulence and transmissibility and update their orders as appropriate.

Routes of transmission for a novel infectious agent or toxin may be poorly understood at the beginning of a crisis, requiring officials to reassess mandates and restrictions in light of new evidence. For any given agent or toxin, the routes of transmission may be respiratory (via droplets that are directly inhaled or ingested or indirectly transmitted via "fomites," such as door handles), fecal-oral contact (which is usually indirect via contaminated water or food), sexual contact, oral contact (direct or indirect, via shared utensils or drinks), or skin contact (direct or indirect via shared bedding, towels, or clothing). Laboratory studies and epidemiological investigations tracing the chains of transmission improve our scientific understanding of a novel agent or toxin over time, which may lead to changing public health recommendations.

In the 2020 pandemic, for example, many scientific advisors initially assumed that the exclusive — or at least primary — route of SARS-CoV-2 transmission was large respiratory droplets that spread to others via direct inhalation, handshaking or fomites, leading to recommendations to stay six feet apart (the typical distance by which large droplets fall to the ground), wash hands, and sanitize high-touch surfaces frequently. Over time, consensus shifted to emphasize the risk of transmission through small droplets capable of floating in the air for longer periods played a significant role, leading to recommendations to avoid spending time with non-household members in poorly ventilated indoor spaces even if a distance of 6 feet was maintained. Whether people are capable of transmitting infection in the absence of signature symptoms is a particularly important question for public health recommendations. Initially, scientists assumed SARS-CoV-2 was transmitted by people who felt sick, so they recommended that people wear masks

312. See Gostin \& Wiley, supra note 3, at 347 (defining virulence); id. at 52 (discussing the strengths and weaknesses of mortality and morbidity as measures of disease burden).

313. Id. at 347. 
if they had symptoms. Over time, however, as it became clear that people without symptoms could spread infection, guidelines shifted to recommend face coverings for the general public.

The level of community transmission in a local area is a critical component of risk assessment. Any given activity may be more or less safe depending on how likely it is that someone present is infected. The risks will vary from place to place and time to time, as they have during the 2020 pandemic. Accurately assessing community transmission requires a public health surveillance strategy. Haphazard clinical testing through a fragmentary mix of private, free-market health care providers and publicly financed test sites may not provide reliable data to inform executive-branch decisions. Public health surveillance through random-sample testing, monitoring of sentinel sites, or syndromic surveillance (with or without the use of clinical tests, which may not be available in the early stages of a pandemic or for some agents or toxins) is distinct from clinical testing of people with symptoms or testing of known contacts of cases for quarantine purposes. A disease surveillance strategy should be considered a critical component of pandemic response. Executive officials should be required to describe the public health surveillance strategy they have implemented to monitor and continually reassess the need for varying degrees of compulsory disease control measures.

The capacity of elected officials and judges to navigate these complex scientific concepts varies, which is why I recommend legislatures should build them into statutory authorizations ex ante and should authorize public health agencies and their leaders - not governors or mayors - to issue compulsory social distancing and face mask orders. For the most part, judges have done an admirable job of navigating the evolving scientific understanding regarding SARS-CoV-2 and COVID-19. Most judges have not exhibited the same skepticism as some litigants with regard to the government's assertions that COVID-19 is a serious communicable disease that spreads rapidly from person to person via respiratory transmission. In South Bay, Chief Justice Roberts relied on evidence that the risk of transmission for SARS-CoV-2 is greatest where "people ... congregate in large groups [or] remain in close proximity for extended periods." 314 His reasoning captured the current scientific understanding regarding the risks of SARS-CoV-2 transmission better than the prefatory clauses of the executive orders he permitted to stand.

Statutory guardrails demanding greater clarity and transparency of the scientific reasoning behind social distancing restrictions and face covering mandates will make it easier for courts to assess whether they are arbitrary and capricious. For well-reasoned orders, transparency may also enhance public trust

314. S. Bay United Pentecostal Church v. Newsom, 140 S. Ct. 1613, 1613 (2020) (denying injunctive relief) (Roberts, C.J., concurring). 
and cooperation. As a constitutional matter, strict scrutiny will require a stronger government justification and more narrowly tailored measures than my proposed disclosure requirements would ensure. But the coronavirus cases suggest courts are unlikely to apply strict scrutiny to many types of social distancing measures. When religious liberty, fundamental rights, or suspect classifications are at issue, statutory requirements should trigger executive-branch officials to more clearly articulate their reasoning in preparation for more searching judicial review.

B. Statutes Should Authorize a Graded Range of Interventions and Classifications of Services, Businesses, and Activities as Essential or HighPriority Should be Developed in Advance

Ideally, public health emergency statutes should offer health officials a graded range of interventions, ${ }^{315}$ allowing them to dial compulsory social distancing measures up or down as needed to respond to changing local conditions (see Figure 1). Mandating use of the least restrictive alternative for every form of compulsory social distancing and face covering — as Gostin, Burris, and Lazzarini recommended for individually targeted restrictions ${ }^{316}$ — would not be consistent with constitutional standards. As the coronavirus cases have demonstrated, most courts in most instances will require only that the measure have a rational basis. Following the recommendations of public health law scholars, the MSEHPA and state statutes influenced by it, mandate use of the least restrictive alternative for compulsory testing, treatment, isolation, quarantine, and vaccination. Compulsory social distancing and face covering orders are less invasive than these individually targeted measures. Although commentators typically use the term quarantine to describe stay-at-home orders, a truly compulsory quarantine order imposes significantly more limitations on personal movement. Quarantine orders may also be enforced by significantly more invasive policing than stay-at-home orders. In 2020 , orders directing the general public to stay at home have included broad exceptions for "essential" work and movement and have largely (though not exclusively) been enforced through voluntary compliance and warnings. Subjecting all compulsory social distancing and face covering requirements to the equivalent of strict scrutiny in the courts could overly constrain common-sense measures. The longstanding public health standard of reasonable necessity, with some additional limits to ensure measures do not discriminate on the basis of religion and do not unduly burden the exercise of fundamental rights probably strikes a better balance between public health needs and individual rights.

To ensure that emergency measures satisfy rational basis requirements (and perhaps also increase the likelihood they will withstand heightened scrutiny if

315. Gostin, Burris \& Lazzarini, supra note 15, at. at 123-24.

316. Id. 
courts apply it) legislation should also provide guidance regarding classifications among businesses and activities. Executive officials have struggled to draw distinctions among businesses in ways that "ensure[] that similarly situated entities would be treated the same." 317 Statutes should specifically authorize health officials to address higher-risk settings based on the best available evidence while providing exceptions for high-priority services (life-sustaining, essential, or otherwise) guided by legislative pronouncements. Statutes authorizing a graded range of interventions would empower health officials to draw difficult distinctions and thus avoid more sweeping (but less discriminatory) restrictions.

Statutory provisions should specifically authorize executive-branch officials to develop classifications that designate which facilities and activities are likely to pose higher risks for various routes of transmission. That could be swimming pools and fountains for water-borne infections transmitted through the fecal-oral route, such as polio. Or it could be bars, dine-in restaurants, and other places where people tend to congregate for long periods of time indoors for infections transmitted through small respiratory droplets, such as SARS-CoV-2.

To define which workers and businesses should be permitted to continue onsite operations even when a stay-at-home order and widespread business closures are in effect, some leaders have looked to external sources for guidance. Pennsylvania's orders, for example, relied on the North American Industry Classification System (NAICS), a code developed by the federal Office of Management and Budget and used by the U.S. Census Bureau for classification purposes. ${ }^{318}$ Other states relied on the list of critical infrastructure workers identified by the federal Cybersecurity \& Infrastructure Security Agency (CISA) to draft exemptions from their stay-at-home orders. ${ }^{319}$ These sources should be directly incorporated into authorizing legislation to ensure classifications are clear, well-vetted, and withstand rational basis review. Other priorities, such as child care and education, might also be designated by the legislature as having high public priority. Ultimately, health authorities should be authorized to override

317. Friends of Danny DeVito v. Wolf, 227 A.3d 872, 881 (Pa. 2020).

318. Id.

319. Hartman v. Acton, Case No. 2:20-CV-1952, 2020 WL 1932896, *6 (S.D. Ohio Apr. 21, 2020) (rejecting equal protection, procedural due process, and substantive due process arguments to the Ohio Department of Health's March 22, 2020 stay-at-home order); see also CYBERSECURITY AND INFRASTRUCTURE SEC. AGENCY, ADVISORY MEMORANDUM ON IDENTIFICATION OF ESSENTIAL CRitical Infrastructure Workers During COVID-19 Response (Mar. 28, 2020) ("The Cybersecurity and Infrastructure Security Agency (CISA) executes the Secretary of Homeland Security's authorities to secure critical infrastructure. Consistent with these authorities, CISA has developed, in collaboration with other federal agencies, State and local governments, and the private sector, an 'Essential Critical Infrastructure Workforce' advisory list. This list is intended to help State, local, tribal and territorial officials as they work to protect their communities, while ensuring continuity of functions critical to public health and safety, as well as economic and national security."). 
predetermined priorities based on risk-based classifications, as warranted by the best available scientific understanding regarding the nature of the pandemic threat. But establishing legislative priorities in advance may help executive orders that impose looser limits on high-priority settings withstand judicial review.

\section{Substantive Standards Should Ensure Orders are Neutral Laws of General Applicability that Do Not Discriminate on the Basis of Religion}

Typical religious worship services bear all the hallmarks of a high-risk setting for SARS-CoV-2 transmission and could certainly pose similar risks in a future pandemic. Congregants tend to gather indoors with people from multiple households, talking or singing for an hour or more. To withstand scrutiny under Catholic Diocese, emergency orders should describe the gatherings to which they apply and the capacity limits they impose in terms that are tailored to these risks, rather than imposing location- or purpose-specific restrictions on houses of worship or religious services. ${ }^{320}$

Under Catholic Diocese, prohibitions on gatherings, capacity limits on gathering places, and any other restrictions must be drafted as "neutral" laws of "general applicability" 321 that do not "single out houses of worship" for restrictions that do not apply to other settings - including commercial establishments, factories, and public services deemed "essential." ${ }^{, 22}$ It is no longer sufficient for state and local governments to apply "[s]imilar or more severe restrictions ... to comparable secular gatherings, including lectures, concerts, movie showings, spectator sports, and theatrical performances, where large groups of people gather in close proximity for extended periods of time," as suggested by Chief Justice Roberts in his South Bay concurrence. ${ }^{323}$ Departing from the Court's approach in South Bay, Catholic Diocese found that even an order exempting activities Roberts

320. See Lindsay F. Wiley, The Role of Religious Liberty in (the Development of) Social Distancing Law, Berkeley Ctr. for Religion, Peace \& World Affairs (June 3, 2020), https://berkleycenter.georgetown.edu/responses/the-role-of-religious-liberty-in-the-developmentof-social-distancing-law.

321. Church of the Lukumi Babalu Aye, Inc. v. City of Hialeah, 508 U.S. 520, 533 (1993). In addition, public health emergency statutes should provide an express exemption from the state's Religious Freedom Restoration Act, if it has one. Not all social distancing orders run afoul of state RFRAs. See, e.g., Cassell v. Snyders, 458 F.Supp. 3d 981 (N.D. Ill. May 3, 2020) (holding state RFRA claim was unlikely to succeed on the merits because "no equally effective but less restrictive alternatives are available under these circumstances"). But it is an issue the legislature should address.

322. Roman Catholic Diocese of Brooklyn v. Cuomo, 141 S. Ct. 63 (2020). Whether lighter restrictions for schools or essential factories would be permissible was not addressed in the case in detail, but the majority did describe schools and factories as having "contributed to the spread of COVID-19" and being "treated less harshly" than the plaintiffs. In reality, however, the challenged order directed local health departments to close schools. N.Y. Exec. Order No. 202.68 (Oct. 6, 2020).

323. S. Bay United Pentacostal Church v. Newsom, 140 S. Ct. 1613 (Roberts, C.J. concurring) (emphasis added). 
deemed "dissimilar ... such as operating grocery stores, banks, and laundromats, in which people neither congregate in large groups nor remain in close proximity for extended periods" 324 could be deemed discriminatory based solely on the fact that it singles out houses of worship or religious gatherings by name. ${ }^{325}$

State and local officials could issue (and new legislation should authorize in specific terms) orders prohibiting sustained gatherings in which more than a certain number of individuals or people from more than a certain number of households spend sustained time together in close contact, regardless of where those gatherings take place. Orders could specifically exempt transitory collections of people who are moving through the same space for only brief periods of time. This exemption could permit lower-risk retail stores and many essential workplaces to remain open even as sustained gatherings are restricted. Another approach would be to order (and specifically authorize in new legislation) capacity limits that would apply to all facilities, regardless of their "essential" status. These "ultraneutral" approaches may ultimately prove untenable in jurisdictions that wish to permit on-site instruction in schools or even on-site work at places whose operations cannot be halted without impeding access to essential goods and services.

Even before Catholic Diocese, many state and local governments had backed off of limits on religious services, even when cases and hospitalizations are surging and even as they have re-tightened limits on similarly high-risk settings like bars, dine-in restaurants, theaters, and other entertainment venues. In one of the first orders to reimpose restrictions in response to the summer wave, Arizona Governor Doug Ducey re-imposed a ban on gatherings of 50 or more people but exempted activities protected by the First Amendment, an exemption not made in the state's March ban. ${ }^{326}$ Catholic Diocese is likely to prompt most jurisdictions to adopt a similarly hands-off approach to religious houses of worship — and perhaps to other activities protected by the First Amendment as well. But legislation should not assume that such draconian constitutional constraints will be applied by courts in future pandemics that pose different or greater risks. Authorizing legislation should support the ability of health officials to draw distinctions based on the risk of transmission, while avoiding singling out houses of worship for specific restrictions.

324. Id.; see also Roberts v. Neace, 457 F. Supp. 3d 595, 600 (E.D. Ky. 2020) (“It is abundantly clear that the 'object or purpose of' Kentucky's mass gathering ban is not 'the suppression of religion or religious conduct.' To the contrary, the plain text of the challenged order categorically bans all 'mass gatherings' as a means of preventing the spread of a life-threatening virus.") (quoting Church of the Lukumi Babalu Aye, Inc. v. City of Hialeah, 508 U.S. 520, 533 (1993)).

325. See Roman Catholic Diocese of Brooklyn, $141 \mathrm{~S}$. Ct.

326. See Ariz. Exec. Order No. 2020-43, supra note 148. 


\section{Statutes Should Mandate Provision of Supportive Measures, Legal Protections, and Accommodation of Safer Alternatives to Restricted Activities within Available Means}

Mandates and restrictions in the absence of social supports to increase voluntary cooperation and minimize secondary harms threaten to exacerbate unjust health disparities along racial, socioeconomic, gender, and disability lines. Moreover, social supports help maintain the public's trust, bolstering the effectiveness of public health measures. Due to logistical, legal, and ethical constraints, restrictions that are mandatory in theory rely on widespread voluntary cooperation in practice. Throughout a public health crisis, sustained social supports to enable safe compliance with restrictions and guidelines and spread the burdens as widely as the benefits are absolutely crucial to the success of the public health response.

The legislature should condition the validity of mandatory orders on reasonable steps by executive-branch officials to provide supports and accommodations for safer alternatives to restricted activities, within available resources. Supports, legal protections, and removal of legal barriers to safer alternatives to restricted activities should be implemented in multiple settings. Governmental responsibility should be exercised immediately to secure the health and safety of people in custody, detention, and foster care, including through dedensification. Upon initiation of school and business closures and orders to stay at home, governments should act immediately to ensure safe, sanitary, and accessible housing conditions. Officials should strongly consider halting eviction and utility shut-offs to secure housing stability in the midst of a crisis. ${ }^{327}$ People experiencing homelessness should be exempted from enforcement of mandatory orders to shelter in place. Moreover, safe, sanitary, and uncrowded shelter that is physically accessible for people with disabilities should be offered to people who are unhoused, experiencing homelessness, or living in communal settings. Supports, accommodations, and legal protections are also needed to shield people exposed to work-related risks, including critical-infrastructure workers, low-wage workers, and people who share a home with workers exposed to on-the-job risks.

Regardless of whether a new statutory requirement is adopted, health officials should work with affected businesses, organizations, and households to help them adapt to and minimize the impacts of social, economic, educational, and cultural disruptions. Authorities should also provide information to the general public and any particularly affected groups about available resources for mental health support, nutrition support, educational assistance, and other social services

327. Elmsford Apartment Associates, LLC v. Cuomo, 2020 WL 3498456 (S.D.N.Y. June 29, 2020) (granting defendant's motion for summary judgment dismissing plaintiff apartment owners' due process and regulatory takings challenge to state eviction moratorium order). 
available to assist with meeting essential needs and coping with disruptions. They should provide guidance and support for the general public and any particularly affected groups, businesses, or organizations regarding safer alternatives to restricted activities, including by providing logistical support and access to public spaces and facilities. This guidance and support should be provided in coordination with other federal, state, local, and tribal government authorities and private organizations.

A statutory mandate to take reasonable steps within available resources would require health officials to demonstrate that they are making an effort to provide supports without overly constraining their ability to impose restrictions. I have borrowed this approach - referred to as "progressive realization" - from international human rights instruments that require member states to demonstrate that they are taking steps to fulfill their affirmative obligations. ${ }^{328}$ In situations where federal financial support is not forthcoming - as has been the case in for much of 2020 - state and local government actions would be held to a standard that takes their lack of resources into account. An assessment of the concrete steps officials have taken to support and accommodate safer alternatives to restricted activities could be part of judicial review, which could be guided by flexible statutory guidelines based on a progressive realization principle.

\section{E. Criminal Enforcement Against Individuals Should be Authorized Only if Justified as the Least Restrictive Alternative}

I have argued that a statutory requirement that compulsory social distancing or face covering orders must be justified as the least restrictive alternative available to achieve the government's purpose would be inappropriate in most situations. But here, I carve out an exception. Criminal enforcement against individuals who violate social distancing and face mask orders should be deployed by executivebranch officials and authorized by new public health emergency statutes only as a last resort. There are multiple alternatives that should be pursued, or at least deemed futile based on the best available evidence, prior to imposing or threatening criminal penalties to enforce restrictions on personal movement or mandates for individuals to wear face coverings. Communication campaigns, support for safer alternatives to restricted activities, and administrative sanctions and civil penalties for licensed businesses and other organizations should be prioritized over criminal enforcement against individuals. Legislatures should require executive officials to justify criminal enforcement as the least restrictive alternative available to achieve a compelling state purpose.

328. UN Committee on Economic, Social and Cultural Rights, General Comment No. 3: The Nature of States Parties' Obligations (Dec. 14, 1990), E/1991/23, available at https://www.refworld.org/docid/4538838e10.html . 
In the absence of criminal enforcement, compulsory mandates and restrictions on individual behavior - requirements to wear masks, to refrain from interacting with people from another household, even in a private home, or requirements to stay home except for expressly permitted purposes - are really just hortatory mandates (an intentional oxymoron) or muscular recommendations. ${ }^{329}$ If so, what is the advantage of issuing an order with "the power of a rule" but no mechanism for enforcement. What is the power of a rule without the threat of enforcement? Why not simply issue an advisory, as some state and many local governments have done?

Some officials appear to believe that their commands are more likely to be heeded if they come in the form of a mandatory order, even if there is no penalty for violations. Perhaps they are right. Until further evidence is developed, I believe it would be premature for new legislation to impose a least restrictive alternative standard on orders to stay at home, or limit gatherings, or wear face coverings so long as those orders are not accompanied by criminal penalties.

Minimal enforcement efforts may be one reason we still have few answers to the question of whether ordering the general public to stay at home is truly constitutionally permissible. Though courts have granted wide leeway to stay at home orders in 2020, surely the result would be different if militarized police forces were patrolling the streets, conducting raids on private homes, or arresting people by the thousands — instead of merely by the dozens ${ }^{330}$ — for violations. Widespread criminal enforcement simply isn't logistically feasible when a pandemic affects so many parts of the country simultaneously, but the next crisis could strike a more limited geographic area. Criminal enforcement of compulsory social distancing or face mask orders should require strong justification. If the courts might be reluctant to demand it, legislatures should.

\section{CONCLUSION}

Reformers seeking to modernize public health emergency laws at the turn of the twenty-first century focused primarily on individually targeted measures that are highly restrictive (quarantine and isolation orders) or invasive (tests, physical examinations, and vaccination). The statutory guardrails they recommended assumed that procedural protections (individual rights to notice, hearings, and representation by counsel) to ensure an individualized risk assessment and use of the least restrictive alternative were both feasible and constitutionally (or at least ethically) required. In the absence of criminal enforcement against individuals,

329. I plan to address this question in a follow-up project.

330. Ashley Southall, Scrutiny of Social-Distance Policing as 35 of 40 Arrested Are Black, N.Y. Times (May 7, 2020), https://www.nytimes.com/2020/05/07/nyregion/nypd-social-distancing-racecoronavirus.html. 
compulsory social distancing and face covering orders are less restrictive of fundamental rights than individually targeted measures. At the same time, they cause far more disruption to social, economic, and cultural activity. Are individualized risk assessments, individually enforceable procedural rights, and statutes mandating use of the least restrictive alternative the appropriate mechanisms for constraining the use of these powers? The courts appear to be answering in the negative. Unfortunately, many judges have relied on suspension standards of review to avoid clarifying the relationship between social distancing and individual rights. But most judges who have delved more deeply into these issues have found that rational basis review — not strict scrutiny — applies to most social distancing and face mask orders.

But if constitutional protections for civil liberties will not substantially constrain the blunt instrument of social distancing beyond the limited contexts of religious worship, abortion rights, and gun sales, what will? I believe the answer lies in the other key tension at the heart of public health law - between expertisedriven regulation and democratic governance. Scientific risk assessments are critical to public health governance, ${ }^{331}$ but pandemic response - like any other form of public health intervention - also requires moral and policy choices. ${ }^{332}$ Fully insulating pandemic mitigation measures from the requirements of transparency and accountability that typically adhere to government action is untenable in a constitutional democracy. Judges are appropriately reluctant to rely on constitutional protections for civil liberties - some of which rely on in turn on unsettled and untested doctrines - to usurp control. They may be more comfortable reviewing executive officials' compliance with statutory standards that express the legislature's preferences regarding the appropriate balance between competing policy priorities in a public health crisis. Statutes should set forth the legislature's ex ante policy determinations and robust requirements of transparency and consistency with the best available scientific understanding as well as requirements for executive-branch officials to offer guidance, accommodations, and support for safer alternatives to restricted activities and services. These requirements are a better fit for constraining compulsory social distancing than individual rights to procedural protections.

In some states, some legislators are so offended by what they perceive to be executive overreach that they are seeking to strip officials of existing emergency powers. ${ }^{333}$ Specific authorizations subject to rigorous statutory guardrails offer an

331. Gostin \& WILEY, supra note 3, at 52 ("science-based risk assessments provide a surer grounding for decisionmaking and avoid reflexive actions based on irrational fears, speculation, stereotypes, or myths").

332. Id. ("public health has a sociopolitical dimension that reasonably takes community values into account").

333. See Wiley \& Vladeck, Coronavirus, Civil Liberties, and the Courts: The Case Against 
alternative that would express the legislature's concerns about unbridled executive authority without tying the government to the mast. Even those who feel stay-athome orders went too far in the spring of 2020 must recognize that the current pandemic is an evolving situation with the potential to become more dangerous over time. Moreover, a future epidemic could pose a threat coronavirus-response critics might view as more severe - with a higher case-fatality rate or higher mortality for children, for example.

Pre-coronavirus pandemic plans - such as the CDC's 2004 plan for possible SARS resurgence - caution that the most extreme disease control measures "[m]ay be controversial because of infringement on personal liberties," and that it "[m]ay be difficult to solicit cooperation for extended periods, particularly if the rationale is not readily apparent or was not clearly explained." ${ }^{334}$ They advise that implementation "[r]equires excellent communication mechanisms to inform affected persons and to maintain public confidence in the appropriateness of the chosen course of action; [m] ay need to provide replacements for affected activities (e.g., school, essential service providers); and [m] ust address mental health and financial support for affected population. ${ }^{335}$ Elected and appointed officials would do well to keep this advice in mind as they navigate the challenges ahead. Clear communication of goals and supports to enable compliance and minimize secondary harms are critical. The public's trust is a scarce and precious resource in a pandemic and the worst of this crisis may yet be ahead of us. State legislatures are beginning to weigh in on the pandemic response. Stripping executive officials of authority to respond to the crisis - as some legislators are seeking to do - is an untenable solution that puts the lives and wellbeing of the populace at risk. Statutory guardrails for executive actions to implement social distancing and mandate the use of PPE are needed, however, to ensure that civil liberties, economic, social, and cultural needs are balanced against public health necessities in a way that promotes democratic accountability and transparency.

'Suspending' Judicial Review, supra note 8. 334. CDC (2004), supra note 71, at 7.

335. Id. 